\title{
THE PRICE WE PAY FOR A SPECIALISED SOCIETY: DO TAX DISPUTES REQUIRE GREATER JUDICIAL SPECIALISATION?
}

\author{
Sarah Miles*
}

In recent years, a review of the Judicature Act 1908 and the introduction of the Judicature Modernisation Bill have enlivened the debate over the structure and character of the New Zealand court system. A key issue that the recent review and reforms have brought to the fore is whether greater judicial specialisation is advantageous at the High Court level. This article considers whether tax cases, in particular, warrant greater judicial specialisation. The article draws from experiences of specialised tax adjudication in foreign jurisdictions and evaluates the efficacy of existing specialisation in the New Zealand system, as well as considering whether the nature of tax law lends itself to specialisation. The conclusion is that greater judicial specialisation in respect of tax cases is undesirable.

\section{INTRODUCTION}

Modern society is incredibly specialised. This reaches across most professions; doctors may specialise in microscopic facets of anatomy, engineers and manufacturers may exclusively produce tiny parts of machinery, and lawyers may solely practise in recondite areas of law. Within these professions, the advances and expertise that specialists achieve often mean that the benefits of specialisation are regarded as axiomatic. Yet, since its inception as a generalist bench, the New Zealand judiciary has remained resistant to this trend towards specialisation. It may be that this signals a failing of the judiciary to adapt, or perhaps judging simply remains an area in which the price of specialisation is more pronounced. It is often said that "taxes are the price we pay for a civilised

* Submitted as a part of the LLB(Hons) programme at Victoria University of Wellington. 
society", ${ }^{1}$ but this article asks: what is the price that we pay for an increasingly specialised society, as regards judicial specialisation for New Zealand tax law cases?

Across the New Zealand legal system, dissatisfaction with the ordinary courts has led to an increase in demand for specialist courts and judges. A survey by the New Zealand Bar Association indicated that 84 per cent of members supported judicial specialisation. ${ }^{2}$ Prominent members of the legal community have spoken out in favour of judicial specialisation, ${ }^{3}$ including Tony Molloy QC, ${ }^{4}$ James Farmer $\mathrm{QC}^{5}$ and the Attorney-General Chris Finlayson. ${ }^{6}$ In response to the growing pressure for specialisation, the past few decades have seen an ad hoc and reactionary proliferation of tribunals and specialised adjudicators, ${ }^{7}$ reflecting a perception that decision making must be increasingly specialised to serve the interests of justice. Nonetheless, judicial specialisation has attracted opposition from a large number of judges, ${ }^{8}$ including Chief Justice Sian Elias. ${ }^{9}$ The Law Commission's comprehensive review of the Judicature Act $1908^{10}$ and the introduction of the Judicature Modernisation Bill, ${ }^{11}$ which implements the Commission's recommendations, have reinvigorated the ongoing debate over judicial specialisation in the High Court.

1 This quote is most often attributed to Justice Oliver Wendell Holmes, Jr, as originating from his dissenting judgment in Compañia General de Tabacos de Filipinas v Collector of Internal Revenue 275 US 87 (1927) at 100 .

2 The New Zealand Bar Association "Submission to the Law Commission on the Review of the Judicature Act 1908" as cited in Law Commission Review of the Judicature Act 1908: Towards a New Courts Act (NZLC R126, 2012) at 104.

3 Phil Taylor "Justice in the Firing Line" The New Zealand Herald (online ed, Auckland, 5 May 2012).

4 Tony Molloy "New Zealand: Cuckoos in the Nest in an Otherwise Promising Trust and Investment Jurisdiction" Offshore Investment (New Zealand, November 2009).

5 James Farmer "The High Court in Review" (8 October 2012) James Farmer QC <www.jamesfarmerqc.co.nz>.

6 Christopher Finlayson, Attorney-General of New Zealand "Access to Justice, Legal Representation and the Rule of Law" (speech to the Legal Research Foundation, 23 October 2009).

7 Law Commission Striking the Balance (NZLC PP51, 2002) at 78-90; and Law Commission Tribunals in New Zealand (NZLC IP6, 2008) at appendix 1.

8 Law Commission, above n 2, at 103.

9 Rod Vaughan "Twitchy lawyers put heat under Chief Justice" The National Business Review (online ed, New Zealand, 23 August 2012); and Cabinet Social Policy Committee Paper "Government response to the Law Commission's report Review of the Judicature Act 1908: Towards a New Courts Act" (April 2013) at [16].

10 Law Commission, above $\mathrm{n} 2$.

11 Judicature Modernisation Bill 2013 (178-2). 
Tax law is frequently singled out as a prime candidate for greater specialisation ${ }^{12}$ and judicial tax specialisation has developed in many foreign jurisdictions. The introduction of specialist judges, courts or panels stands to have a significant effect on the process and results of the court system. Accordingly, it is necessary to consider the merits of specialisation in a principled manner, particularly when the benefits of specialisation tend to be more readily apparent than its consequences.

This article considers whether increased adjudicative tax specialisation is desirable in New Zealand, considering the "price" we pay for judicial specialisation, as well as its benefits. The article is divided into four parts. Part I considers judicial specialisation generally, observing the often unprincipled trend towards specialisation in New Zealand and warning against further specialisation in the absence of strong justification. Part II evaluates the level of judicial specialisation in New Zealand in respect of tax law, with particular reference to the position of the Taxation Review Authority. It concludes that problems with tax specialisation in New Zealand are best addressed by reform to existing means of specialisation rather than overlaying additional judicial specialisation. Part III surveys a selection of specialised overseas jurisdictions to gain insights into the realities of judicial specialisation and to establish whether New Zealand should follow suit. Lastly, Part IV applies Legomsky's set of normative criteria to determine whether the nature of tax law is suitable for greater judicial specialisation. ${ }^{13}$

\section{SURVEYING SPECIALISATION IN NEW ZEALAND}

\section{A "General" History of Specialisation}

Historically, New Zealand's court system has been characterised by a preference for generalist judges. More recently, there has been a growing trend towards specialisation, which is particularly evident in the growth of tribunals.

New Zealand established its first court, the Supreme Court, in 1841 as a general court. The New Zealand court system indicated an early inclination towards judicial generalism, with a wide jurisdiction that streamlined common law and equity jurisdictions, and simplified procedural rules. ${ }^{14}$

12 The Law Commission recommended the establishment of specialist panels in taxation, intellectual property, competition and admiralty law: Law Commission Delivering Justice for All: A Vision for New Zealand Courts and Tribunals (NZLC R85, 2004) at 267.

13 SH Legomsky Specialized Justice - Courts, Administrative Tribunals and a Cross-National Theory of Specialization (Oxford University Press, Oxford, 1990) at 20-32.

14 For instance, the Supreme Court Ordinance 18415 Vict 1 stated that the Court's jurisdiction incorporated testamentary, lunacy, vice-admiralty and criminal matters. See also Law Commission Review of the Judicature Act 1908: Towards a Consolidated Courts Act (NZLC IP29, 2012) at 110. 
These generalist origins are attributable to the small size of the judiciary, which necessitated that a few judges covered a vast range of cases. ${ }^{15}$

The advent of specialist courts happened gradually with the establishment of the predecessors to the modern Māori Land Court and Māori Appellate Court in 1865, ${ }^{16}$ the Employment Court in $1894^{17}$ and the Environment Court in 1953. ${ }^{18}$ The scattered introduction of these specialised courts indicates the absence of an underlying rationale or cohesive vision for the New Zealand court system.

In 1968, New Zealand took a considerable leap towards judicial specialisation with the introduction of the Administrative Division of the High Court. The short-lived Division was abolished in 1991, following Law Commission recommendations. ${ }^{19}$ Amongst the reasons for the division's demise was a caseload that "lacked the critical mass needed for successful specialty" 20 and the growing interest and expertise of High Court judges in public law as it became more common, obviating the need for specialist judges.

15 GA Wood "Construction and Reform: The establishment of the New Zealand Supreme Court" (1968) 5 VUWLR 1 at 3.

16 First established in 1865 under the Native Lands Act 1865, s 5 as the Native Land Court. Now established in Te Ture Whenua Maori Act 1993 (Maori Land Act 1993), ss 6 and 50.

17 The Court can be traced to the Court of Arbitration established under the Industrial Conciliation and Arbitration Act 1894. It is now established under the Employment Relations Act 2000, s 187.

18 The Court first existed as an Appeal Board under the Town and Country Planning Act 1953, then became a Planning Tribunal under the Town and Country Planning Act 1977. The Resource Management Amendment Act 1996, s 6 introduced the modern Environment Court.

19 Law Commission The Structure of the Courts (NZLC R7, 1989).

20 Law Commission Seeking Solutions: Options for Change to the New Zealand Court System (NZLC PP52, 2002) at 157. 


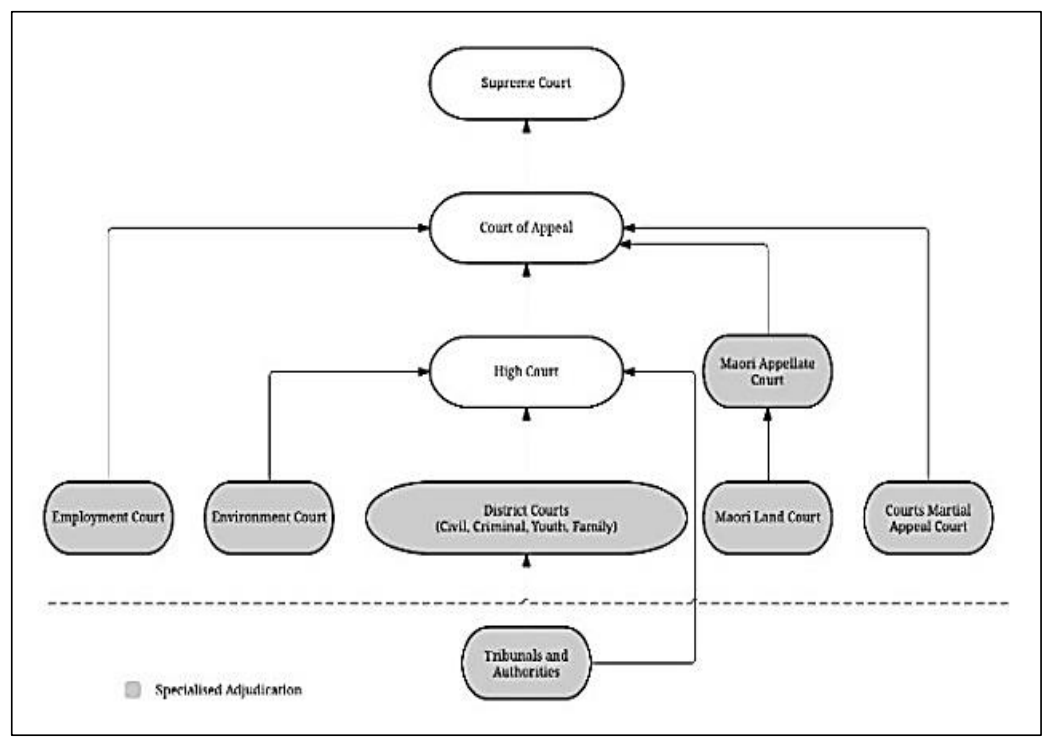

Figure 1: Specialisation in the New Zealand court hierarchy ${ }^{21}$

More recently, there has been a proliferation of tribunals dealing with specialist matters. ${ }^{22}$ Once introduced, these tribunals have proved resistant to "overhaul and rationalisation". ${ }^{23} \mathrm{New}$ Zealand still has well over 100 disparate tribunals, despite repeated attempts by the Law Commission to streamline the tribunal system. ${ }^{24}$ The Commission has remarked that the tribunals "have grown in an ad hoc and random fashion. They have been set up to meet specific needs, but not according to any rational pattern." 25

Specialist courts, too, have developed in an ad hoc manner, and it is often unclear why specialisation was considered necessary for particular areas of law over others. ${ }^{26}$ The creators of specialist courts often acted with little forethought as to the courts' operation as part of the general

21 This diagram is reproduced from "Diagram of the Courts Structure" Courts of New Zealand <www.courtsofnz.govt.nz>.

22 Law Commission Striking the Balance, above n 7, at 78-90; Law Commission Tribunals in New Zealand, above n 7, at Appendix 1; See also W John Hopkins "Order from Chaos? Tribunal Law Reform in New Zealand" (2009) 1 JIA Law TA 47.

23 Law Commission Tribunals in New Zealand, above $\mathrm{n} 7$, at 6

24 Trevor Daya-Winterbottom "Specialist Courts and Tribunals" (2004) 12 Waikato L Rev 21 at 22.

25 Law Commission Tribunals in New Zealand, above $\mathrm{n} 7$, at 6

26 Law Commission Striking the Balance, above n 7, at 50; See also the comments of Roger Kerr, who states: "I believe there are good arguments for abolishing most of them [existing specialist courts]": Roger Kerr "Judging the Judiciary" (paper presented to Wellington District Law Society Conference, Ruapehu, June 1998) at 8. 
court structure. ${ }^{27}$ Instead, the establishment of specialist courts was motivated by a response to an immediate and pragmatic need, ${ }^{28}$ or by a desire to privilege or influence decisions in a particular area. For instance, the Native Land Court was introduced to further the native land policies of the time by converting title more expeditiously than the ordinary courts. The Native Land Act's preamble expressed this purpose, without consideration of the principles behind specialisation or its consequences on the wider court system. ${ }^{29}$ Similarly, the first Arbitration Court (now the Employment Court) was established by William Reeves, who described the Industrial Conciliation and Arbitration Act 1894 as his "pet measure". ${ }^{30}$ The Employment Court's history seems also to be borne out of a specific desire to introduce a specialisation without regard for the implications on the cohesion of the court system.

Many commentators agree that specialisation is often primarily motivated by a desire to influence judicial processes and results. Baum observes: ${ }^{31}$

Most often, proposals for specialized courts have been adopted because advocates and decision makers sought to shape the substance of judicial policy ... The perceived virtues of specialization as such have played only a limited part in the adoption of particular proposals.

Robertson agrees, concluding: ${ }^{32}$

Specialist Courts are created when some interest group does not believe that equal application of the laws by judges applying the traditional canons of statutory interpretation and the traditional values of the common law will result in decisions that favour its own ideology and interests.

Going forward, proposals for greater judicial specialisation must be critically considered to prevent deference to interest groups and to avoid opening a Pandora's Box of fragmented and unwieldy courts.

\section{B Means of Specialisation}

Specialisation may be internal, through the creation of divisions within the general court system, such as for the Youth Court and the Family Court, or it may be external, such as for the creation of

27 The same cannot be said for the introduction of the Administrative Division, which followed the PALRC Report: Public and Administrative Law Reform Committee of New Zealand Appeals from Administrative Tribunals (First Report, 1968) [PALRC Report].

28 Daya-Winterbottom, above n 24, at 24.

29 The Native Lands Act 1865, preamble.

30 Keith Sinclair William Pember Reeves: New Zealand Fabian (Clarendon Press, Oxford, 1965) at 151.

31 Lawrence Baum Specializing the Courts (University of Chicago Press, Chicago, 2011) at 214.

32 Bernard Robertson "The Status and Jurisdiction of the New Zealand Employment Court" (paper presented to the New Zealand Business Roundtable, Wellington, August 1996). 
the separate Environment Court. ${ }^{33}$ This distinction does not always reflect the degree of judicial separation of the particular court; Environment Court judges are also District Court judges, whereas Employment Court and Māori Land Court judges sit separately. ${ }^{34}$ Panel systems and specialist lists may also act as an inroad in to the judiciary's general nature. For instance, the commercial list in the High Court adds a greater degree of specialisation. ${ }^{35}$ Different means of specialisation strike a different balance between generalisation and specialisation.

Specialisation can take place at any level of the judicial system. It is most likely to have the greatest impact at the High Court level, ${ }^{36}$ leaving appellate judges to benefit from the expertise of the judge who first pieced together the facts of the case in the lower court, when this expertise is often touted as the primary justification for specialisation.

This article primarily contemplates a tax court or a tax panel. A specialist tax court would sit at High Court level and have exclusive jurisdiction to hear tax cases. A panel would be composed of High Court judges who have particular tax expertise. Tax cases would be allocated to judges on the panel and panel judges would continue to hear other High Court cases.

\section{JUDICIAL SPECIALISATION IN RESPECT OF TAX LAW}

\section{A What is Tax Law?}

It is necessary to demarcate what tax law is before considering whether it demands greater judicial specialisation. An inability to define a discrete area of law can stand as an initial obstacle to specialisation. For instance, Frankel has questioned whether commercial specialisation is appropriate, noting the overlap where "commercial law may involve contractual matters of either a generalist or a specialist nature (such as construction contracts), insolvency matters, tax issues, property matters [and] intellectual property matters". ${ }^{37}$ Tax law is less burdened by this problem than many other legal disciplines. ${ }^{38}$ Tax cases are easily identified through the presence of the Commissioner of Inland

33 Susan Glazebrook "A Specialist Patent or Intellectual Property Court for New Zealand?" (2009) 12 JWIP 524 at 525 .

34 Law Commission, above n 12, at 16.

35 The commercial list was established in 1987. The list provides a pre-trial procedure for certain commercial cases, but returns cases to the High Court to be allocated to any High Court judge. Although the list was initially successful, nowadays only a small fraction of commercial cases is commenced by the commercial list: see generally Law Commission, above n 12, at 267-269.

36 See S H Legomsky Specialized Justice - Courts, Administrative Tribunals and a Cross-National Theory of Specialization (Oxford University Press, Oxford, 1990) at 9.

37 Susy Frankel "Facilitating and Regulating Commerce: Commentary on the Conference Session 'Regulating and Facilitating Commerce'" in David Carter and Matthew Palmer (eds) Roles and Perspectives in the Law: Essays in Honour of Sir Ivor Richardson (Victoria University Press, Wellington, 2002) 391 at 394.

38 But see the discussion of the Degree of Isolation of tax law in Part V(D) of this article. 
Revenue (IRD) as a party. Tax cases typically deal with assessments of tax decisions or determinations of the Commissioner that are authorised by the various income taxation Acts. The simple identification of tax law means that it is less likely to be affected by jurisdictional conflicts, which can introduce second order litigation over which court ought to hear a particular case.

\section{B Current New Zealand Tax Judicial Specialisation}

Presently, there is no formal mechanism that provides for tax disputes to be dealt with by specialist judges in the general New Zealand court hierarchy. However, the disputes process and the Taxation Review Authority (TRA) give tax cases exposure to specialist practitioners and judges. Analysis of these forums reveals that the New Zealand tax system already incorporates a significant degree of specialisation in the valuable early stages of a tax dispute. While the process has some shortcomings, reforms to elements of the existing process are more likely to be effective than superimposing an extra layer of specialisation to the court system.

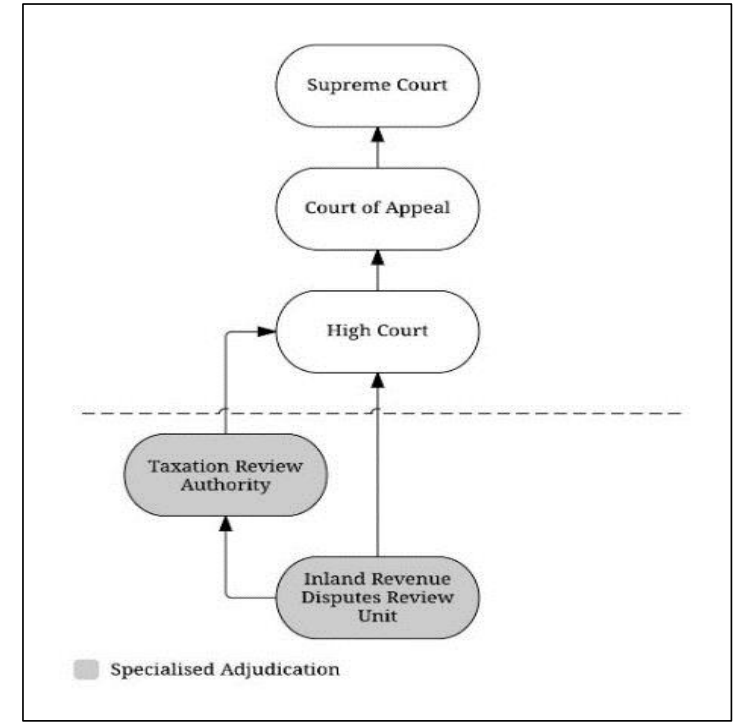

Figure 2: New Zealand tax disputes structure

\section{Taxation Review Authority}

\section{Overview of the TRA}

Taxation was possibly the first area of British law to develop a recognisable tribunal, with the establishment of a board of three commissioners under the 1799 Income Tax Act. ${ }^{39}$ New Zealand

39 The Duties Upon Income Act 1799 (UK). See also Law Commission Tribunals in New Zealand, above n 7 , at 13 . 
followed this model, establishing a Board of Review in $1891,{ }^{40}$ although New Zealand has since adopted several different adjudicative bodies for tax disputes. ${ }^{41}$ The TRA provides an important initial opportunity for prospective litigants to have their cases heard by a specialist judge.

The Taxation Review Authorities Act 1994 provides for the establishment of one or more Taxation Review Authorities. ${ }^{42}$ Technically, the Authority need not be a judge. Section 5(3) provides that an experienced lawyer of not less than seven years' practice may also act as the Authority. In practice, this has not occurred. Since 2012, a single District Court Judge, Judge AA Sinclair, has acted as the Authority. ${ }^{43}$

The Governor-General appoints persons to the Authority on the recommendation of the Minister of Justice. ${ }^{44}$ The tenure of an appointment is for a term not exceeding seven years. ${ }^{45}$ Authorities may be reappointed, which has occurred frequently, with Judge Barber serving for some 31 years from $1981-2012 .{ }^{46}$

The TRA's judicial appointment process is different to the usual appointment of judges in New Zealand: ${ }^{47}$ the Governor-General appoints judges on the Attorney-General's advice. ${ }^{48}$ The divergence in appointment practice is troubling, because the ministerial involvement introduces a political dimension to judicial appointments. In view of the Government's substantial interest in the funding it receives from taxation, it seems inappropriate to give the Minister power over the appointment of a specialist Authority. The Law Commission has recommended the introduction of consistent appointment guidelines for tribunals, but suggested that the Minister of Justice, as a supposedly "disinterested party", be responsible for tribunal appointments. ${ }^{49}$ The Government did not implement the recommendation, but a 2014 Cabinet Paper proposed that the Ministry of Justice publish the

40 Land and Income Assessment Act 1891, s 20.

41 See generally, Law Commission Tribunals in New Zealand, above n 7, at 16.

42 Taxation Review Authorities Act 1994, s 5.

43 "Appointment of a Taxation Review Authority" (7 June 2012) 66 New Zealand Gazette 1820 at 1820.

44 Taxation Review Authorities Act 1994, s 5(4).

45 Taxation Review Authorities Act 1994, s 6(1). The Governor-General has the power to suspend or remove an Authority for engaging in an outside occupation, being unable to perform the functions of the office, becoming bankrupt, neglecting their duty, or for misconduct; Taxation Review Authorities Act 1994, s 6(3).

46 See Appendix 2 for a table of previous Authorities.

47 However, this position is not unique for a tribunal such as the Taxation Review Authority. Unlike the courts, many tribunals have different advising ministers.

48 See generally Phillip A. Joseph "Appointment, Discipline and Removal of Judges in New Zealand" in HP Lee (ed) Judiciaries in Comparative Perspective (Cambridge University Press, Cambridge, 2011).

49 Law Commission Tribunal Reform (NZLC SP20, 2008) at 13. 
tribunal appointment and reappointment process where it is common across tribunals. ${ }^{50}$ This proposal may boost the transparency of TRA appointments.

The limited tenure of a judge is another inroad into judicial independence. It gives a member of the executive the power to appoint different judges after an arbitrary period if the Authority reaches decisions that conflict with governmental interests. Although the need for judicial independence is intensified in respect of tax law, granting lifetime tenure to Authorities is not without problems too. If a single judge was granted lifetime tenure and developed a track record favouring the Commissioner, many taxpayers would be left without recourse. The Courts and Tribunals Enhancements Cabinet Paper proposes to amend the appointment term of an Authority to a term not exceeding five years. ${ }^{51}$ Apart from Judge Sinclair's five-year appointment in 2012, a seven-year term has been standard for Authorities. This reduction may jeopardise the TRA's independence, which is particularly crucial in light of the relationship between the state and the taxpayer, or it may prevent long-term appropriation and damaged credibility of the Authority.

The Authority is technically an administrative tribunal, but in practice, it acts like a court of first instance. Indeed, some foreign commentators have classified the Authority as a specialist tax court. ${ }^{52}$ Under s 138P(1) of the Tax Administration Act 1994, the Authority is empowered to review assessments, including the power to confirm, cancel or vary an assessment, or to reduce the amount of an assessment. Taxpayers can generally file proceedings with the TRA or the High Court ${ }^{53}$ and there are powers to have the case transferred from the TRA to the High Court. ${ }^{54}$ Litigants usually have appeal rights to the High Court if the amount of tax involved exceeds $\$ 2,000$ or the net loss exceeds $\$ 4,000 .{ }^{55}$ Appeal may be granted to the Court of Appeal in some circumstances. ${ }^{56} \mathrm{~A}$ specialist tax court at High Court level would remove any potential strategic advantage taxpayers have

50 See Cabinet Social Policy Committee Courts and Tribunals Enhancements (24 June 2014) at 5-6.

51 At 5 .

52 Suzette Chapple "Income Tax Dispute Resolution: Can We Learn From Other Jurisdictions" (1999) 2 JAT 312 at 322. North P described the former Board of Review as a "judicial body" in Reckitt \& Colman (New Zealand) Ltd $\vee$ Taxation Board of Review [1966] NZLR 1032 (CA) at 1037. The Court of Appeal held that the Authority was a "court of inferior jurisdiction" for the purposes of s 67 of the Judicature Act in Jacobs $v$ Commissioner of Inland Revenue [2012] NZCA 30, (2012) 25 NZTC 20-108.

53 Carin Holmes and Kevin Holmes "Judicial System of New Zealand: Legal Remedies in the New Zealand Tax System" (2010) 16 Asia-Pacific Tax Bulletin 63 at 65.

54 Tax Administration Act 1994, s 138N.

55 Taxation Review Authorities Act 1994, s 26.

56 Taxation Review Authorities Act 1994, ss 24(4), 26 and 28. 
in choosing between the TRA and the High Court, which presents an initial argument for specialisation. ${ }^{57}$

\section{Declining cases: a failure of judicial specialisation?}

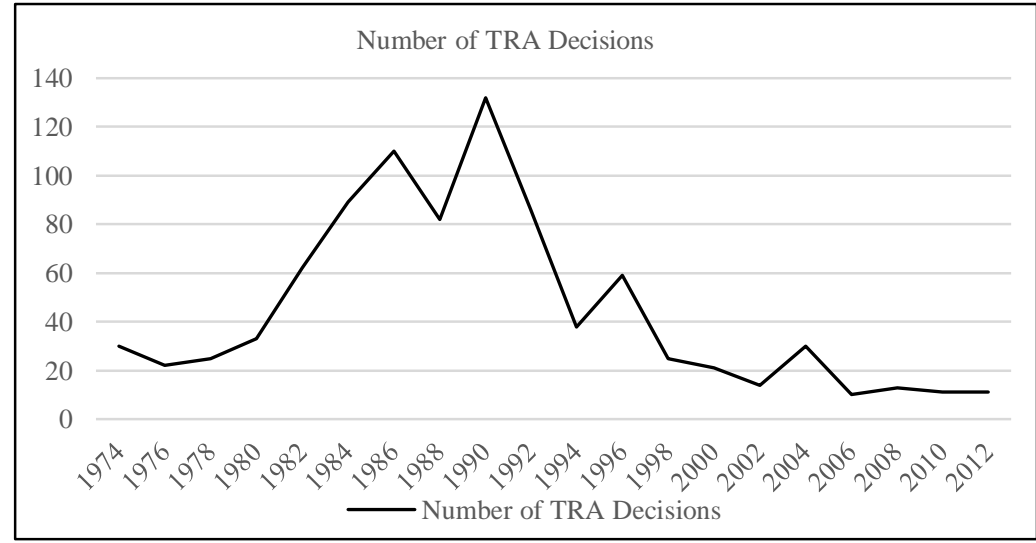

Figure 3: Number of TRA decisions by year ${ }^{58}$

The Authority has experienced a great decline in cases. A joint submission of the Law Society and the National Tax Committee of the New Zealand Institute of Chartered Accountants compares the 64 cases taken to the Authority in 1996 to the 13 cases that it had in $2006 .{ }^{59}$ A single Judge, for whom the Authority's cases take up approximately only a quarter of her time, now deals with the work performed by four judges for whom Authority work occupied 80 per cent of their time in $1996 .{ }^{60}$ The small claims jurisdiction of the Authority was removed in $2011,{ }^{61}$ after having been used less than 10

57 The Treasury identified this "tactical opportunity for taxpayers" as an issue in its discussion of a specialist tax court but did not find it persuasive: The Treasury Tax Review 2001 (Issues Paper, 2001) at 24.

58 The number of tax cases is no longer collected by the Inland Revenue Department (IRD). These statistics are based on the number of cases reported in the New Zealand Tax Cases (NZTC). For a full table of the figures, see Appendix 1.

59 The New Zealand Law Society and the New Zealand Institute of Chartered Accountants "Joint Submission to the Finance and Expenditure Committee on the Taxation (Tax Administration and Remedial Matters) Bill" at 7-10 as cited in Andrew Maples "Resolving Small Tax Disputes in New Zealand - Is There A Better Way?" (2011) 6 JIA Law TA 96 at 98.

60 However, Judge Barber notes there were really only two active Taxation Review judges, even when more district court judges held warrants for the Authority. Judge Barber commented that tax cases took up around 80 per cent of his time in 1988, with the other 20 per cent dedicated to other criminal and civil court work: Ann Riley and others "International Conference Courts with Income Tax Jurisdiction: Conference Transcript" (1988) 8 Va Tax Rev 443 at 445.

61 The small claims jurisdiction was removed by the Tax Administration and Remedial Matters Act 2011. 
times since it was introduced. ${ }^{62}$ A decrease in sitting days also lends some empirical evidence to the deteriorating role of the Authority. ${ }^{63}$ As figure 3 demonstrates, the High Court still deals with the bulk of tax cases. The falling-off in cases to the Authority risks weakening the benefits of specialisation; without a steady stream of cases for judges to build expertise, the benefits of specialisation may wane. More critically, it may be that this decline signals a taxpayer preference to have cases heard before generalist judges.

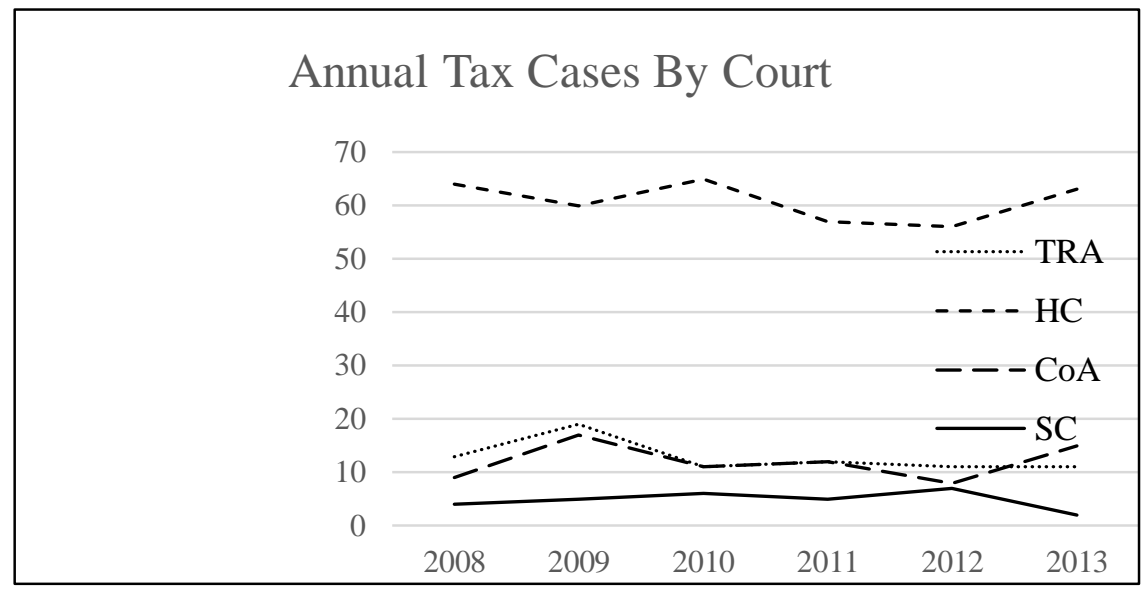

\section{Figure 4: Annual tax cases by court ${ }^{64}$}

However, it is not entirely fair to evaluate the TRA's effectiveness through a case volume comparison with the High Court. The High Court holds powers that the Authority does not, such as being vested with the sole power to hear judicial reviews and more extensive powers to award costs to the successful party (although this may be advantageous to some litigants). ${ }^{65}$ Another key difference is that TRA hearings are conducted privately and published anonymously. ${ }^{66}$ The High Court may also be the sensible route for taxpayers who expect to appeal their case further. The

62 New Zealand Master Tax Guide (2013 ed, CCH New Zealand Limited, 2013) at 209.

63 However, the small period for which sitting days were published and the significant effect that a handful of complex cases can have in skewing this data means that its usefulness is reduced: see Appendix 3.

64 The Inland Revenue Department no longer collects the number of tax cases. These statistics are based on the number of Authority decisions reported in the New Zealand Tax Cases (NZTC), and High Court cases on the Ministry of Justice's searchable database of Judicial Decisions Online. For a full table of the figures and explanation of the sources, see Appendix 5.

65 Compare s $51 G$ of the Judicature Act 1908 and pt 14 of the High Court Rules with ss 22 and 22B of the Taxation Review Authorities Act 1994.

66 Taxation Review Authorities Act 1994, s 16(4); and Taxation Review Authorities Regulations 1998, reg $36(2)$. 
Treasury's 2001 Tax Review was reluctant to force commencement at the Authority because it would increase legal costs and lengthen queues, when "many cases currently being initiated at the High Court are likely to be appealed from the Authority if initiated there". ${ }^{67}$ Furthermore, institutional features of the courts, such as the time and cost of hearings which are not necessarily a direct reflection of success of specialisation, are suggested as being the dividing factors between the High Court and the Authority. ${ }^{6}$

Compared to the large amounts of money at stake, the difference between the fees of the High Court and those of the TRA is insignificant, ${ }^{69}$ although the TRA may waive the filing fee where the disputant cannot pay the fee or the proceeding concerns a matter of genuine public interest that the taxpayer would not commence without the waiver. ${ }^{70}$ If the Authority cannot offer significantly less costly dispute resolution, then it is unlikely that High Court level specialisation would deliver this.

Alternatively, the High Court may be preferred as a more expeditious avenue of dispute resolution. TRA decisions seem to take an excessive amount of time. The average age of cases, from Ministry receipt to TRA decision, is 828 days, ${ }^{71}$ excluding 16 adjourned cases that obscure the true average age. The Cabinet Paper outlining these figures makes special mention of the fact that the "tribunal considers very complex and litigious cases, often relating to large companies". ${ }^{72}$ However, information provided in August 2014 by the office of Hon Chester Borrows, Minister for Courts, indicated that work is underway to deliver prompter resolution of tax disputes. The office aims to halve the time taken to deal with matters across the court and tribunal system by 2017, including those matters at the TRA. ${ }^{73}$ The Ministry is delivering this goal on policy and operational levels. The

67 The Treasury Tax Review 2001 (Final Report, October 2001) at [2.21].

68 For instance, see New Zealand Law Society and the New Zealand Institute of Chartered Accountants "Joint Submission to the Finance and Expenditure Committee on the Taxation (Tax Administration and Remedial Matters) Bill" at 7-10.

69 The application fee to have a case heard by the Taxation Review Authority is \$410: Taxation Review Authorities Regulations 1998, reg 10(1). The application fee to have a case heard by the High Court is $\$ 1,350$ and there are further hearing fees, depending on how many court days the matter takes: High Court Fees Regulations 2013, sch 1.

70 Taxation Review Authorities Regulations 1998, reg 10A.

71 Cabinet Social Policy Committee, above n 50, appendix 1.

72 At 19

73 Email from Oliver Searle (Office of Chester Borrows, Minister for Courts) to Sarah Miles regarding Taxation Review Authority Enhancements (29 August 2014). 
Minister is preparing the Courts and Tribunals Enhanced Services (CATES) Bill, which is expected to be released toward the end of $2014 .^{74}$ Operationally, the TRA is: $:^{75}$

... focusing in particular on older cases, ensuring the smarter management of tribunals support and judicial resources, and working alongside judicial officers to pro-actively manage cases towards a resolution and reduce the time it takes to release reserved judgments.

This has produced encouraging results. Between 30 April 2013 and 24 August 2014, the average (mean) age of active cases at the Authority has decreased by 19.7 per cent, from taking 1,756 days to 1,410 days. ${ }^{76}$ Additionally, the number of cases in hand has decreased by 66.8 per cent, from 157 cases to $52 .{ }^{77}$ If the unpopularity of the judicially specialised Authority is due to excessive delays, then this progress signals that legislative and operational changes at the level of the Authority are effective solutions, without the need to specialise the general court system. It also suggests that the Authority's supposed failings are not as a result of its specialist nature or the problems associated with that, but more general operational issues.

Indeed, beyond a quantitative assessment of the TRA, it is difficult to draw firm conclusions as to the qualitative success of tax specialisation in New Zealand based on the Authority's record of accomplishment. Sir Ivor Richardson concluded: ${ }^{78}$

I have read hundreds of Taxation Review Authority judgments and numerous High Court judgments too.

I hesitate to generalise or to attempt any kind of ranking. Certainly I have found numerous judgments in

both jurisdictions to be very helpful in the depth of the analysis and reasoning.

While some judges have performed commendably, ${ }^{79}$ the performance of others is open to criticism. Some commentators have observed that Authority decisions are rarely appealed or reversed, ${ }^{80}$ although in some cases this may be symptomatic of unduly brief judgments that do not provide scope to appeal. There have been some issues of inconsistency both within the Authority, and

74 New Zealand Government "Further Improvements to Tribunals Announced" (press release, 24 June 2014).

75 Email from Oliver Searle, above n 73.

76 Email from Oliver Searle, above n 73.

77 Email from Oliver Searle, above n 73

78 Ivor Richardson "Observations from the Bench" (address to the NZ Society of Accountants 1994 Tax Conference, November 1994).

79 Hansard records praise in the House for the performance of the Authorities: "the role of the Taxation Review Authority... has been discharged manfully by officials and members of the authority for a number of years": (9 November 2004) 621 NZPD 16775.

80 Paul Stephan "Courts with Income Tax Jurisdiction: An International Comparison" (1988) 8 Va Tax Rev 233 at 242. See also Riley and others, above n 60, at 477. 
between the Authority and the High Court. ${ }^{81}$ This could highlight the risk of leaving adjudication to a small pool of experts: poor decision making is more concentrated, and the quality and outcome of decisions is patchy and inconsistent, both intra-tribunally and inter-tribunally.

Figure 2 demonstrates that the sharpest decline in cases before the Authority occurs after 1990, with cases peaking in 1984-1990. One explanation for this may be the appointment of less preferred judges to the Authority; with only one judge sitting as the Authority, it may seem likely that the Authority's caseload decline can be ascribed to litigants avoiding a particular judge. Yet, this conclusion is unsupported by caseload trends. The caseload decline in the early 1990s does not correspond with a personnel change; Judges Barber, Bathgate and Keane were authorities throughout both the peak and declining periods of the Authority. ${ }^{82}$ The drop also corresponds to an overall drop in tax cases across all the courts. ${ }^{83}$ More likely, the drop in cases corresponds with certain events in the history of taxation. For instance, the introduction of goods and services tax in 1986 introduced extra litigation, while a major reform of the disputes process and enactment of the self-assessment regime in 1994 and the settlements policy in 1995 reduced the number of cases proceeding to the Authority. ${ }^{84}$ Changes in the volume of tax cases before the Authority are more often brought about by changes to the law or reforms to the adjudication process. This underscores the need for a flexible and adaptable court system in the dynamic subject of tax law. Greater High Court-level specialisation risks damaging this flexibility by rigidly fixing the number of High Court judges able to hear cases.

\section{Disputes}

Before a tax dispute arrives before a judge, it will have already passed through the disputes resolution process, which gives cases early exposure to a range of tax specialists to ensure that issues are identified and that factual disputes are addressed early in the challenge process. ${ }^{85}$ The Review

81 See Susan Glazebrook "Revenue Law" (1993) 4 NZ Recent Law Review 180. See also David Dunbar's criticism of Judge Barber's decisions in certain income-splitting cases, even though it is acknowledged that Judge Barber "is an extremely experienced Taxation Review Authority with over 20 years' judicial experience": David Dunbar "Judicial Techniques for Controlling the New Zealand General Anti-Avoidance Rule: The Scheme and Purpose Approach, from Challenge Corporation to Peterson" (2006) 12 NZJTLP 324 at 340 .

82 See Appendix 2 for a table of appointments to the Authority.

83 William Young $\mathrm{J}$ tracks a similar decline in tax cases to the High Court in "Tax Disputes in New Zealand" (2009) 4 JATTA 1 at 8.

84 Former Taxation Review Authority, Judge Barber, similarly observed how fluctuations in the nature of cases driven by legislative and policy changes can affect overall case volumes, commenting: "I rather think that the claims by employees under the Fourth Schedule to the Income Tax Act 1976 have fallen off a little, as have farming loss cases, but as I mention below, the rental loss situation is a new problem area and there appears to be a greater proportion of investigation hearings than previously": Paul Barber "Tax and the Courts" (paper presented to the 1984 Residential Taxation Seminar, Wellington, November 1984) at 2.

85 Holmes and Holmes, above n 53, at 64. The Review Unit also significantly limits the number of cases reaching the courts, with approximately one third of reviews in favour of the taxpayer: Zoë Prebble and John Prebble 
Unit is an "independent" 86 branch within the IRD, staffed by qualified accountants and lawyers. ${ }^{87}$ The Disputes Review Unit delivers adjudication reports based on the papers, which help prospective litigants to determine their litigation risks according to specialist opinions. Key reviews and amendments to the disputes process in 2003 and 2010 have helped to achieve its objectives. ${ }^{88}$ The IRD has suggested that the decline in tax cases before the courts is evidence that the disputes process is functioning effectively and reducing the need for litigation. ${ }^{89}$ However, the disputes resolution process is not a complete substitute for litigation. Justice Glazebrook emphasises the important societal benefits that the disputes process lacks, observing: "Court judgments have precedential value and the court process itself can act as a check on executive power, something which is essential to the rule of law". 90

The decline in cases progressing to the Authority may suggest that the disputes process is too expensive or time consuming for many taxpayers, putting pressure on them to concede cases that might otherwise be upheld in court. ${ }^{91}$ Direct reforms to the disputes process best address this concern, rather than overlaying judicial specialisation. In 2011, the IRD made several changes to the disputes process aimed at improving its timeliness. The changes include an assurance of more focused notices

"New Zealand" in Karen Brown (ed) A Comparative Look at Regulation of Corporate Tax Avoidance (Springer, Netherlands, 2012) 243 at 248.

86 Glazebrook J notes: "While the Unit is a separate unit within the Office of the Chief Tax Counsel, it is still an internal administrative mechanism without the independence of the courts and without the public scrutiny of its decisions in terms of the open justice principle, which again is so fundamental to our system of justice (and indeed of parliamentary democracy generally)": Susan Glazebrook "Taxation Disputes in New Zealand" (paper presented to Australasian Tax Teachers Association (ATTA) Conference, Auckland, January 2013) at 17.

87 New Zealand Master Tax Guide, above n 62, at 222; "Office of the Chief Tax Counsel (OCTC): Disputes Review Unit" (9 July 2013) Inland Revenue Department <www.ird.govt.nz>.

88 A review of the process described the objectives of the process as being "to improve the quality and timeliness of assessments and to reduce the likelihood and grounds for subsequent litigation": Inland Revenue Department and the Treasury Disputes: A Review - An Officials' Issues Paper (July 2010) at [1.4]; and Inland Revenue Department Resolving tax disputes: a Legislative Review (July 2003). Similarly, Commentary to the Taxation (Annual Rates, Venture Capital and Miscellaneous Provisions Bill) 2004 identifies that "the main objective of the disputes process is to have legislation and administrative practices which encourage disputes to be dealt with fairly, efficiently, and quickly before they get to court": as cited in James Coleman and Eugen Trombitas "Disputes with the IRD" (New Zealand Law Society Seminar, March 2009).

89 Inland Revenue Department Resolving Tax Disputes: A Legislative Review (Policy Advice Division, July 2003) at 2.

90 Glazebrook, above $\mathrm{n} 86$, at 17.

91 Brendan Brown "New Zealand Case Law Developments" (paper presented to the New Zealand Institute of Chartered Accountants 2012 Tax Conference, October 2012). See also Mark Keating "New Zealand's Tax Dispute Procedure - Time for a Change" (2008) 14 NZJTLP 425; and Glazebrook, above n 86, at 11. 
of proposed adjustments and clarification of the taxpayer's limited opportunity to opt out of the disputes process. ${ }^{92}$ IRD also set tighter internal deadlines and processes for monitoring deadlines. ${ }^{93}$

\section{E Settlements}

Settlement policies also explain the decline in cases to the Authority and High Court. Section 6A of the Tax Administration Act 1994 was introduced in 1995, allowing the Commissioner to settle for less than "the highest net revenue that is practicable within the law" in some circumstances. ${ }^{94}$ Subsequent cases affirmed the Commissioner's power to settle disputes on a commercial basis. ${ }^{95}$ It is arguable that the case decline does not signal a failed application of judicial specialisation, but reflects changes to disputes and settlements practices. The shortcomings of these specialised stages of the process are best addressed, and are currently being addressed, by targeted reforms aimed at the particular delay or problem. High Court specialisation cannot be contemplated without reference to existing, specialised, stages of the tax disputes process.

Overall, the TRA and disputes/settlements processes offer taxpayers an effective level of specialisation in New Zealand that would not be enhanced by the introduction of a specialist court or judges. Problems identified with the independence, cost and timeliness of these specialisations are not usually related to their specialisation per se, and are being addressed by a range of reforms led by the Minister for Courts, and internally at the IRD.

\section{F De Facto Specialisation}

As well as specialisation at the IRD and the TRA, there is arguably a de facto practice of specialisation on the New Zealand bench. Certainly, a small handful of judges have been instrumental in the development of New Zealand's tax law. ${ }^{96}$ Butler has observed an allocation pattern in tax cases

92 Disputes Resolution Process Commenced by the Commissioner of Inland Revenue (Inland Revenue Department, SPS 11/05, November 2011) at [65]-[92] and [172]-[195]; and Disputes Resolution Process Commenced by a Taxpayer (Inland Revenue Department, SPS 11/06, November 2011) at [34]-[141] and [203]-[230].

93 Disputes Resolution Process Commenced by the Commissioner of Inland Revenue, above n 92, at [93]-[97]; and Disputes Resolution Process Commenced by a Taxpayer, above n 92, at [138]-[141].

94 See generally Mark Keating "Settlement of Tax Disputes: A Step Backwards" (paper presented to New Zealand Law Society Tax Conference 2011, September 2011) at 32-37.

95 Auckland Gas Co Ltd v Commissioner of Inland Revenue [1999] 2 NZLR 409 (CA) at 417; Attorney-General v Steelfort Engineering Co Ltd (1999) 1 NZCC 61,030 (CA) at 61,036. See also Care and Management of the Taxes Covered by the Inland Revenue Acts - Section 6 A(2) and (3) of the Tax Administration Act 1994 (Inland Revenue Department, IS 10/07, 22 October 2010).

96 For instance, McLeod claims: "It is generally accepted that Sir Ivor is a tax expert who has had more influence on tax law and practice than any other New Zealand Judge": Rob McLeod "Collecting Taxes" (2002) 33 VUWLR 793 at 793. See also Geoff Harley "Reflections on Sir Ivor Richardson's Career in Tax Cases" (2002) 8 NZJTLP 141. 
between 1999 and 2001, noting, "Sir Ivor Richardson, Justice Blanchard, Justice Gault, and the High Court judges Justices McGechan, Robertson, and Salmon heard more tax law cases than their colleagues". ${ }^{97}$ There are dangers in relying on de facto specialisation; it lacks transparency, removes the benefits of organised professional development and prevents the introduction of safeguards against the perception of bias, isolation or idiosyncratic developments in the law.

\section{G Appointments}

More broadly, many newly appointed judges have backgrounds in commercial law, contrary to the perception that High Court judges disproportionately come from criminal law backgrounds. ${ }^{98}$ Of 20 appointments from 1 July 2010, 14 were judges with experience in commercial law firms. ${ }^{99}$ Brown suggests that the appointment of Justice Glazebrook to the Supreme Court, who has considerable experience as a tax practitioner, is of "particular interest to tax practitioners". ${ }^{100}$ The appointment of more judges with a broad commercial background is a valuable way of equipping the judiciary to deal with tax cases, without many of the consequences associated with full models of specialisation. Although there is no legislative requirement that the Attorney-General consider the diversity of experience and backgrounds of candidates, ${ }^{101}$ this factor influences the appointments process protocol ${ }^{102}$ and practice. ${ }^{103}$ A specialist tax court or panel might make it simpler and more transparent

97 Petra Butler "The Assignment of Cases to Judges" (2003) 1 NZJPIL 83 at 91

98 For instance, Roger Kerr comments that judges come from a narrow range of backgrounds, commenting that "there is a ... potential source of judicial talent that is under-used because the system is clearly loaded against this group. A procedure of consulting senior judges inevitably favours the litigators who appear before them. Left largely out of account are the transactional or commercial lawyers who arguably undertake the real development of our law by devising original solutions to new problems": Roger Kerr "Judging the Judiciary" (paper presented to Wellington District Law Society Conference, Ruapehu, June 1998) at 5.

99 Brown, above $\mathrm{n} 91$, at 10 .

100 At 10 .

101 But see cl 94 of the Judicature Modernisation Bill 2013 (178-2), which requires the Attorney-General to publish information concerning judicial appointment processes.

102 The Attorney-General has recognised that "legal ability", which includes a "sound knowledge of the law and experience of its application", is a criterion for High Court appointment. The Appointment Protocol recognises a broad range of legal experience and does not suggest any requirement for the Attorney-General to consider what a candidate would bring to the overall diversity of experience of the bench. However, the AttorneyGeneral does request a curriculum vitae with a full work history, including a list of significant cases the applicant has appeared in as counsel, as well as general career highlights: Christopher Finlayson "High Court Judges Appointment Protocol" (April 2013) Ministry of Justice <www.justice.govt.nz>.

103 Former Attorney-General, Margaret Wilson stated from her experience that it was important, at least for the Supreme Court, to "reflect a diversity of legal experience": Margaret Wilson "Appointing Judges the New Zealand Way" (2013) 21 Wai L Rev 41 at 47. The Law Commission has also recognised the need to maintain a "horses for courses" approach to appointments when it formulated a set of general principles for the Attorney-General to consider in making appointments: Law Commission, above n 14, at 27. 
to appoint judges based on tax-specific experience, but in light of the High Court's growing commercial strength, this benefit of specialisation is marginal.

\section{H Implications of a Commercial Panel}

The Judicature Modernisation Bill 2013 may have significant implications for the level of tax judicial specialisation in New Zealand. Clause 18 of the Bill establishes a commercial panel in the High Court, to replace the commercial list. Although the Bill does not set out the types of cases that the commercial panel will deal with, it is unlikely to deal with tax cases. The Bill abolishes the existing commercial list, ${ }^{104}$ suggesting that the cases that the commercial panel will determine are likely to remain the same as those dealt with by the commercial list. The commercial list does not incorporate the management of tax cases.

Clause 18(2) of the Bill empowers the Chief High Court Judge, in consultation with the AttorneyGeneral and the Chief Justice, to establish other panels of High Court judges. There has been no suggestion that a High Court tax panel is imminent and the Law Commission was not satisfied that any other panels were justified. ${ }^{105}$ However, the existence of this significant power to create panels is a further reason that a considered debate regarding tax specialisation is crucial. In light of the ad hoc history of judicial specialisation in New Zealand and the divergent judicial views on specialisation, entrusting this power to a sole person may risk a proliferation of specialist panels at the High Court.

\section{THE OVERSEAS EXPERIENCE OF SPECIALISATION}

This Part will compare the approach of several foreign jurisdictions towards specialisation of the judiciary in respect of tax. Many of the jurisdictions compared in this section have dissimilar tax systems to New Zealand, and far larger federal court systems. Bearing in mind these limitations, the United States, Canada, and Australia have been chosen because they share a broad common law heritage and they demonstrate different models of specialisation.

Most countries of a comparable size to New Zealand do not have judicial specialisation for tax matters in the general courts, although many have tax tribunals. ${ }^{106}$ This international consistency with similarly sized countries suggests that New Zealand's court system is striking the appropriate balance for tax judicial specialisation. Of the countries sampled that do incorporate specialisation into the general courts, such as Lebanon, Finland and Slovakia, most do not have dedicated tax specialisation, but administrative courts or divisions. Although New Zealand's now defunct Administrative Division

104 The Bill does not carry forward s 24A of the Judicature Act 1908, which establishes the commercial list.

105 Law Commission, above n 2, at 12.

106 See Appendix 4. 
only had a limited jurisdiction to hear certain sales tax cases, ${ }^{107}$ the division's collapse militates against a return to this system.

\section{A United States of America}

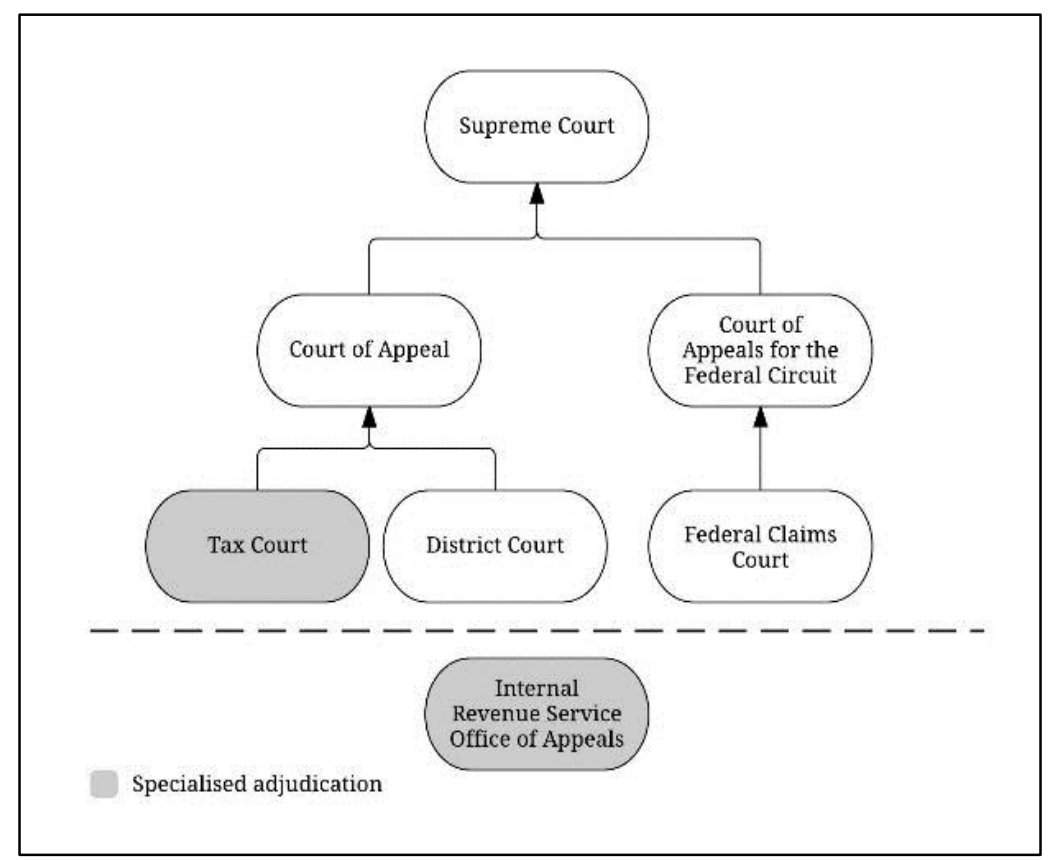

Figure 5: United States tax disputes structure

In 1924, the United States Congress created the Board of Tax Appeals, which evolved to what is now the Tax Court. ${ }^{108}$ The Tax Court has national jurisdiction to hear tax cases. ${ }^{109}$ The United States court system also features several specialised state courts that hear tax disputes in connection with state tax laws. ${ }^{110}$ The Office of Appeals is an independent body by which taxpayers may have their case reviewed before progressing to the Court. ${ }^{111}$ Appeals from the Tax Court go to the general United

107 Legomsky, above n 36, at 56.

108 The name was changed to the Tax Court in 1942 and was again changed to the United States Tax Court by the Tax Reform Act 1969 Pub L No 90-172 83 Stat 730 (1969). See generally Erwin Surrency History of the Federal Courts (Oceana Publications, New York, 1987) at 319-320.

109 "About the Court" (25 May 2011) United States Tax Court < www.ustaxcourt.gov>.

110 For example Oregon Tax Court, Hawaii Tax Appeal Court, Indiana Tax Court, Massachusetts Appellate Tax Board, Minnesota Tax Court, and New Jersey Tax Court.

111 "Appeals... Resolving Tax Disputes" (16 June 2014) Internal Revenue Service <www.irs.gov>. 
States Court of Appeals in the circuit where the taxpayer resides. The taxpayer has the choice of having the case heard in the Tax Court, the District Court, or the Claims Court. The Tax Court is comprised of 19 presidentially appointed judges, ${ }^{112}$ alongside several senior judges and special trial judges. ${ }^{113}$

An obvious strength of the Tax Court is the high degree of expertise of its judges. Baum notes that it is "regular practice" for judges to be chosen to serve on the Tax Court because of their preexisting expertise from specialising in tax law as a practitioner. ${ }^{114}$ The online biographies of Tax Court judges certainly support this claim. ${ }^{115}$ Baum argues that this expertise is likely to produce better decisions and he points to studies that observe a higher rate of Court of Appeal reversals coming from the District Court than the Tax Court. ${ }^{116}$ However, the strength of the United States' tax judiciary is largely a function of the size of the United States, rather than its approach to specialisation. The United States population and tax system are exponentially larger than New Zealand's. In 2013, the United States Tax Court alone had 335 fulltime employees and total budgetary resources of \$48 million. ${ }^{117}$ Judge Barber notes that the key difference between the United States Tax Court and the TRA is size, stating: "We are a very small operation by comparison." 118 The United States' population of some 315 million people compared to New Zealand's 4.5 million suggests that the introduction of a specialist court or panel would probably have a marginal effect on the pool of judicial candidates, which will inevitably lack tax specialists in a small legal community.

Despite the strength of the tax bench, the Tax Court has been criticised for its insularity and its lack of independence and transparency, ${ }^{119}$ suggesting that this criticism of specialist courts is almost unavoidable, regardless of how well executed or the scale of the specialisation. Specialisation, by nature, tends to be tarnished by these problems of appropriation and insularity, even though the extent of benefits from specialisation tends to vary proportionately to the scale of specialisation.

112 Presidential nomination is subject to Senate confirmation.

113 "About the Court" (25 May 2011) United States Tax Court <www.ustaxcourt.gov>.

114 Lawrence Baum "Probing the Effects of Judicial Specialization" (2009) 58 Duke LJ 1667 at 1676.

115 See "Judges" (11 April 2014) United States Tax Court <www.ustaxcourt.gov〉.

116 Baum, above n 31, at 153 .

117 Office of Management and Budget (US) (eds) Fiscal Year 2015 Appendix, Budget of the United States Government (Government Printing Office, 2014) at 40.

118 Riley and others, above n 60, at 474.

119 Leandra Lederman "Tax Appeal: A Proposal to Make the United States Tax Court More Judicial" (2008) 85 Wash U L Rev 1195. 


\section{B Canada}

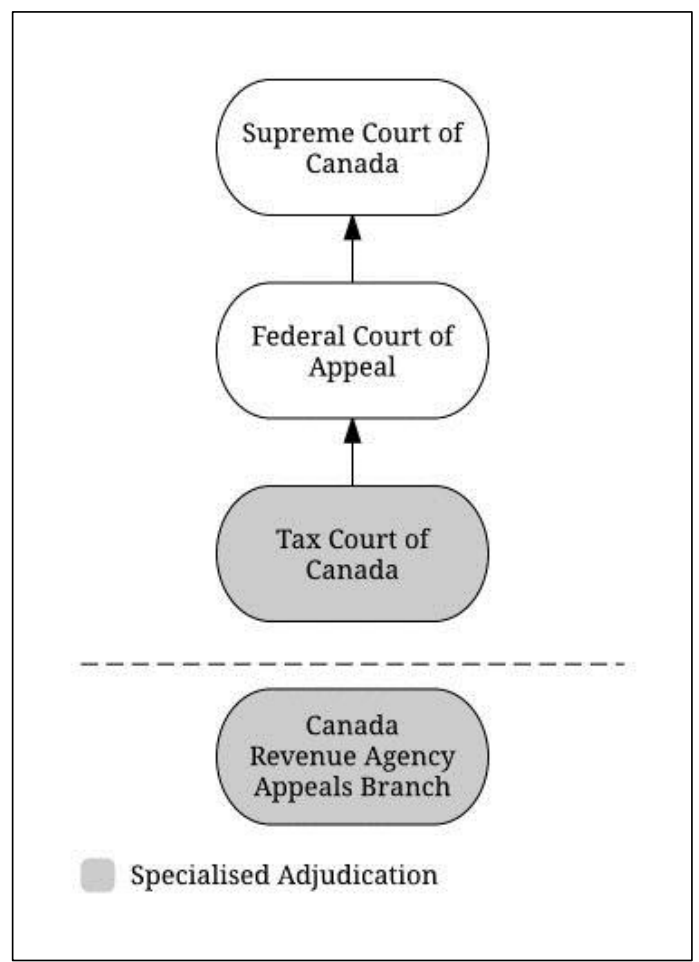

Figure 6: Canadian tax disputes structure

Canada's introduction of a specialist tax court is more recent. The Tax Court of Canada was established in 1983 as a superior federal court of record, ${ }^{120}$ replacing the Tax Review Board. ${ }^{121}$ The Court has exclusive original jurisdiction to hear appeals or matters arising under certain statutes such as the Excise Tax Act and the Income Tax Act. ${ }^{122}$ The Governor in Council appoints judges. ${ }^{123}$ The Court currently consists of a Chief Justice, an Associate Chief Justice and 23 other judges. ${ }^{124}$

120 Tax Court of Canada Act RSC 1985 c T-2, s 3.

121 See Alban Garon and others "Tax Court of Canada: 20th Anniversary Symposium" (2005) 53 Can TJ 135 at 137.

122 Tax Court of Canada Act RSC 1985 c T-2, s 12.

123 Section 4(2).

124 "Judges" (10 June 2014) Tax Court of Canada <www.tcc-cci.gc.ca〉. 
The Court was established to fulfil the recommendations of a report by the Carter Commission, which criticised the independence and prestige of the former Tax Review Board. ${ }^{125}$ A specialist court was recommended to remove suggestions of political interference and to attract more skilled judges, who had begun to view the Tax Board as an inferior tribunal. The Tax Court's mission statement reflects a balancing between the dangers and advantages of judicial specialisation, affirming a commitment to "providing the public with an accessible and efficient appeal process and working together to maintain a fair and independent Court". ${ }^{126}$ By most accounts, the Tax Court is balancing these competing aims effectively. The Court's success is evident in the rejection of a 1997 proposal to consolidate the Federal Court and the Tax Court, with many stakeholders unprepared to surrender the efficiency that the specialised Court was providing. ${ }^{127}$ Overall, the Court receives glowing reports from most commentators, with MacGregor and others commenting: "The Court has garnered respect from both the general public and the tax community." 128

\section{Australia}

Australia has no specialist tax court, but incorporates specialisation at the Administrative Appeals Tribunal (AAT) and in a list and panel system at the Federal Court.

125 Report of the Royal Commission on Taxation (Queen's Printer, 1967).

126 Tax Court of Canada Tax Court of Canada, 1999-2000 Estimates, Report on Plans and Priorities (1999) at 6.

127 Ian MacGregor and others "The Development of the Tax Court of Canada: Status, Jurisdiction, and Stature" (2010) 58 Can TJ 87 at 97.

128 At 98 


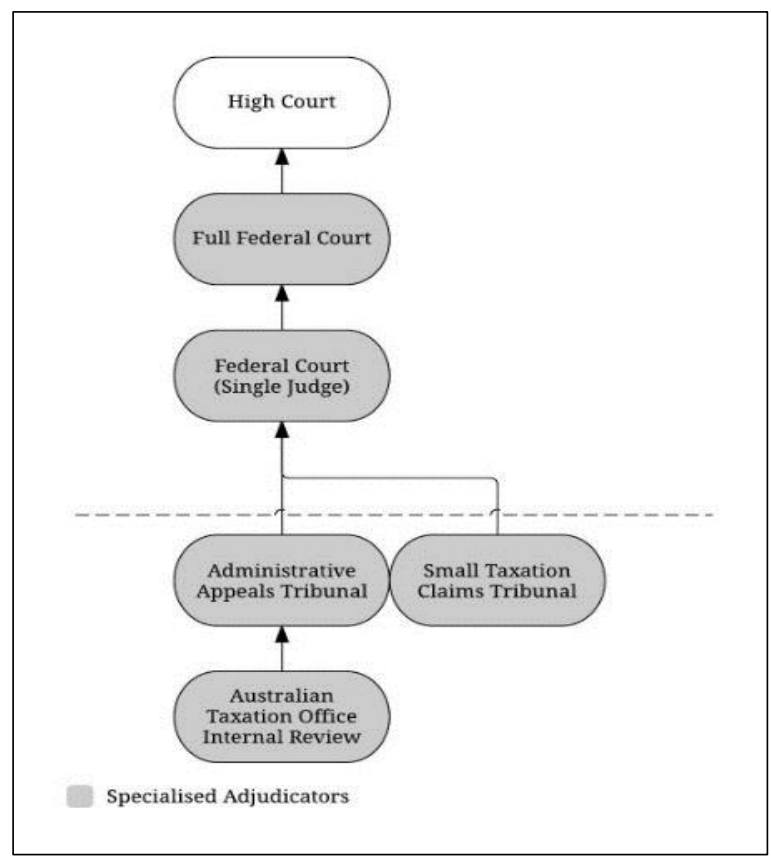

Figure 7: Australian tax disputes structure

Taxpayers can take disputes to the AAT or the Small Taxation Claims Tribunal (STCT) within the AAT if the claim is for less than $\$ 5,000 .{ }^{129}$ Taxpayers may then appeal to the Federal Court to be heard by a single judge, with a further right of appeal to have the full Federal Court hear the case. The final opportunity for appeal is by special leave to the High Court. Interestingly, Australia does not have a sophisticated disputes process before the AAT as New Zealand has before the TRA. Commentators have questioned this gap and suggested that Australia ought to follow New Zealand's practice in this area. ${ }^{130}$

The AAT was established in 1976, replacing the former Board of Review, which was a board with three members: a person from the tax office, an accountant and a lawyer. The Tribunal has been criticised for perpetuating a pro-administration leaning that developed from the Tax Office's influence in appointments to the Board of Review. ${ }^{131}$ Australia's experience reinforces the fact that specialist

129 Administrative Appeals Tribunal Act 1975 (Cth), s 24AC.

130 Chapple, above n 52, at 322.

131 Hugh Ault and Brian Arnold Comparative Income Taxation: A Structural Analysis (Kluwer Law International, 1997) at 19. See also Wayne Gumley "The Taxation Appeals System: An Administrative Law Perspective" in Chis Evans and Abe Greenbaum (eds) Tax Administration: Facing the Challenges of the Future (Prospect Media, St Leonards (NSW), 1998) 299 at 307-308: "The basis for this change was a 
bodies often attract perceptions of bias, which can have devastating consequences for the reputation of the court or tribunal. This lends support to an argument for transferring the TRA appointment powers of the Minister of Justice (as advising minister) to an apolitical office, such as the AttorneyGeneral. Notwithstanding these suggestions of political influence, Downes J has praised the Taxation Appeals division for its strong membership, asserting that "the Tribunal ... began its taxation jurisdiction with a distinguished group of taxation specialists. That position has continued throughout its 25 year history." 132 However, if a much larger country such as Australia struggles to appoint judges whose experience in private firms or government departments does not give rise to perceptions of bias, then New Zealand is sure to struggle to improve on this experience.

The Governor-General appoints members of the AAT as a President, Deputy President, Senior Member or Non-presidential Member. The necessary qualifications for appointment are dependent on the role. ${ }^{133}$ Currently, only 16 of the 84 tribunal members are judges. ${ }^{134}$ Extensive guidelines set out how the President of the Tribunal determines which members hear a particular case. ${ }^{135}$ The care taken in developing these guidelines hints at the sensitivity of panel appointments. If New Zealand were to develop a tax panel at the High Court, it ought to look to Australia's guidelines as a way of lessening the risk of "panel packing", ${ }^{36}$ which the Judicature Modernisation Bill leaves as a very real opportunity. The Bill gives the Chief High Court Judge power to decide the basis on which cases are to be distributed to panel judges, ${ }^{137}$ as well as the power to assign a judge directly to a case. ${ }^{138}$ The result is that the Chief Judge could manipulate the allocation of judges to ensure that judges with certain policy leanings could hear particular cases, in an attempt to influence the case's decision. The guidelines provide general and special rules for constituting the tribunal and a list of matters to be taken into account generally, which reduces the arbitrariness of a single judge's choice in allocating a judge to a panel.

perception by tax practitioners that the presence of former ATO employees as chairpersons undermined the independence of the Boards. A related argument was that the relatively small number of Board members (some of whom were also former ATO officers) created a risk that they would become attuned favourably to arguments regularly presented by ATO advocates before the Board."

132 Garry Downes, President of the Administrative Appeals Tribunal "Twenty Five Years of Tax Cases in the AAT; Eleven years of the "practical business tax" (Corporate Tax Association 2011 GST Corporate Intensive, The Grace Hotel, Sydney, 17 October 2011).

133 Administrative Appeals Tribunal Act 1975, s 7.

134 "Who We Are" (9 September 2014) Administrative Appeals Tribunal <www.aat.gov.au>

135 Administrative Appeals Tribunal Guidelines "Guidelines for Constituting the Tribunal" (14 November 2011).

136 See generally Butler, above n 97, at 85

137 Judicature Modernisation Bill 2013, cl 18(5).

138 Clause 18(6). 
Australia also incorporates a list and panel system for tax cases into the Federal Court. The tax list is geared towards facilitating case management. A tax list co-ordinating judge completes a pro forma questionnaire, leads a scheduling conference, and examines tax cases to ensure that like cases and issues are heard together. ${ }^{139}$ The Practice Note for the tax list provides that the co-ordinating judge will refer cases to the registry to be allocated to a docket judge. The individual docket system then provides for "cases in some areas of law requiring particular expertise (including patents, taxation and admiralty)" to be randomly allocated to members of a specialist panel. ${ }^{140}$ Spender $\mathrm{J}$ claims that the Federal Court's appellate decisions have "a certain authority" even though it is not a separate appeal court, because panels are "formed with specialist judges who tend to have an interest and expertise in one particular area of another". ${ }^{141}$ Typically, the Chief Justice assigns two tax experts and one non-expert to an appeal panel, to balance the expertise against a broad perspective. ${ }^{142}$ Overall, the AAT and the federal panels have been successful. Schabe and Blissenden praise the STCT as "a significant and worthwhile development in tax dispute resolution for which the Federal Government should be commended", ${ }^{143}$ and the panel system has attracted praise in both Australia and New Zealand, but has also been criticised as an elitist system that favours certain judges according to their area of interest and geographical location. ${ }^{144}$ Former Chief Justice Michael Black argues that the combination of the docket system and panels is optimal, asserting that: ${ }^{145}$

In this way, the Federal Court maximises the efficient use of its judicial expertise at trial and on appeal.

At the appellate level, the system provides a facility for constituting appellate benches for specialist cases

that permanent courts of appeal are unlikely to be able to match consistently.

Overall, foreign specialist tax courts and panels have successfully developed an experienced and knowledgeable bench, and an efficient system for tax dispute resolution. Yet, a recurrent criticism of these adjudicative and curial bodies questions their independence, and disapproves of their insularity.

139 Federal Courts of Australia Fast Track (Practice Note CM 8, August 2011).

140 "Individual Docket System" Federal Court of Australia <www.fedcourt.gov.au>.

141 Jeffrey Ernest John Spender "Interview with J.E.J. Spender: An Overview of the Australian Federal Court System" (1990) 16 Brook J Intl L 453 at 458.

142 At 458

143 David Schabe and Michael Blissenden "The Small Taxation Claims Tribunal: The Experience Thus Far" in Chis Evans and Abe Greenbaum (eds) Tax Administration: Facing the Challenges of the Future (Prospect Media, St Leonards (NSW), 1998) 283 at 283.

144 In New Zealand, the Law Commission cited a submission of the Bar Association that referred to concerns over the perception of the tribunal as elitist, but stated that "the concerns that have been raised however do not detract from what is generally seen as the overall success of the regime": Law Commission, above $\mathrm{n} 2$, at 105 .

145 Michael E J Black "The Federal Court of Australia: The First 30 Years - A Survey On the Occasion of Two Anniversaries" (2007) 31 Melb U L Rev 1017 at 1043. 
On the scale that these countries operate on, it may be that the price of specialisation is justifiable. But, for New Zealand, it is likely that concerns over insularity and perceived partiality would accompany specialisation, without the full benefits that these large, well-resourced, specialised tax systems enjoy.

\section{NEW ZEALAND AND SPECIALISATION: APPLYING LEGOMSKY'S CRITERIA}

This Part will apply Legomsky's criteria ${ }^{146}$ to evaluate whether a class of cases should be determined by specialist judges. Legomsky proposed the 12 criteria as a method for determining whether specialisation is desirable, and applied the criteria to the former Administrative Division of the New Zealand High Court. The criteria provide a more principled way to consider specialisation than the responsive, ad hoc process that has characterised the history of judicial specialisation in New Zealand. ${ }^{147}$

\section{A Mix of Law, Fact and Discretion}

\section{Discretion and the General Anti-Avoidance Rule}

The first criterion suggests that discretionary and factual decisions favour specialisation. Discretionary decisions lend themselves to specialisation because the wider the scope of a judge's choice, the more likely that the decision will best employ certain qualities possessed by specialist judges. These qualities include an understanding of the particular policy objectives, a reduced likelihood of oversights, a commitment to the pursuit of coherence, and reduced dependence on the views and adversarial skills of counsel. ${ }^{148}$

Many areas of tax law are highly discretionary. Particularly, the application of general antiavoidance provisions involves a wide judicial discretion. Since the $1960 \mathrm{~s},{ }^{149}$ litigation in respect of the General Anti-Avoidance Rule (GAAR) has been increased so that it now represents a significant component of tax challenges and litigation. ${ }^{150}$ Glazebrook J notes that many of the "most important" tax cases reaching the Supreme Court involve tax avoidance or evasion. ${ }^{151}$ GAAR cases also exert a

146 Legomsky, above n 36, at 20-32.

147 Legomsky's criteria are frequently adopted as the starting-point for analysing the desirability of specialisation. See Glazebrook, above n 33; and Daya-Winterbottom, above n 24.

148 Legomsky, above n 36, at 22-23.

149 Ben Nevis Forestry Ventures Ltd \& Ors v Commissioner of Inland Revenue [2009] NZSC 40, [2009] 2 NZLR 358 at [11].

150 Mark Keating "Tax Avoidance in New Zealand: The Camel's Back that Refuses to Break!" (2011) 17 NZJTLP 115; and Timothy McLeod "'Reconstruction' or 'Destruction'?: The Approach of the Commissioner and the Courts to Section GA 1" (2012) 18 NZJTLP 256 at 256-257.

151 Glazebrook, above n 86, at 3. 
significant economic impact. The "bank conduit" cases involved some of the largest sums in the history of New Zealand litigation, with an estimated $\$ 2.4$ billion in tax and interest claimed by the IRD. ${ }^{152}$

The GAAR provides that "a tax avoidance arrangement is void as against the Commissioner for income tax purposes". ${ }^{153}$ Section YA 1 defines a tax avoidance arrangement imprecisely and circularly, essentially declaring that a tax avoidance arrangement is an arrangement that avoids tax. ${ }^{154}$ New Zealand courts have recognised the inescapable uncertainty of the provision ${ }^{155}$ and Inland Revenue's interpretation statement acknowledged that the courts are left to identify avoidance. ${ }^{156}$ The Supreme Court in Ben Nevis Forestry Ventures Ltd v Commissioner of Inland Revenue formulated the most authoritative test: the parliamentary contemplation test. ${ }^{157}$ However, the test has been criticised for incorporating a "sniff test", allowing judges wide discretion to point to indicia of avoidance such as artificiality, contrivance, and mismatches between the form of an arrangement and its economic and commercial realities, which "contribute to the overall foul smell of a transaction". ${ }^{158}$ When tasked

152 As Prebble puts into perspective, "NZ\$2.4 billion is approximately the total of the annual fees of the New Zealand legal profession and rather more than the \$US1.4 billion (about \$NZ1.9 billion) at issue in the celebrated United States KPMG tax shelter cases of the late 1990s": John Prebble "Tax Avoidance, International Tax Arbitrage, and New Zealand as a Haven for Foreign Capital and Income" (2010) 16 Revue Juridique Polynesienne 169 at 171. See also Michael Littlewood "Tax Avoidance, the Rule of Law and the New Zealand Supreme Court" [2011] 1 NZ L Rev 35.

153 Income Tax Act 2007, s BG 1.

154 The tautology of the definition is reminiscent of Lord MacNaghten's remark that "[i]ncome tax, if I may be pardoned for saying so, is a tax on income" in Attorney General v London County Council [1901] AC 26 (HL) at 35 . The very concept of income tax is to be understood according to ordinary concepts, as identified by judges. The statement illustrates that broad tax concepts are often resistant to capture by precise definitions and that judicial discretion is often necessary and advantageous.

155 The Supreme Court stated that "it is simply not possible to meet the objectives of a general anti-avoidance provision by the use, for example, of precise definitions": Glenharrow Holdings Ltd v Commissioner of Inland Revenue [2008] NZSC 116, [2009] 2 NZLR 359 at [48].

156 The interpretation statement states: "the statutory definition of 'tax avoidance' is not an exhaustive one. Parliament has left it to the courts to identify tax avoidance, and the function of the statutory definition is to confirm that certain defined circumstances, such as future tax liabilities, are not excluded from the scope of tax avoidance": Tax Avoidance and the Interpretation of Sections BG 1 and GA 1 of the Income Tax Act 2007 (Inland Revenue Department, IS 13/01, June 2013) at [14].

157 Ben Nevis Forestry Ventures Ltd v Commissioner of Inland Revenue [2008] NZSC 115, [2009] 2 NZLR 289. The parliamentary contemplation test first considers whether the use made of a specific provision was within its intended scope, and then whether the use of the provision, viewed in the light of the arrangement as a whole, was nevertheless used in a way that was outside of Parliament's contemplation when enacting the provision.

158 Mike Lennard "Two Tribes and an Elephant Called Ben Nevis" (2009) 22 Taxation Today 1; and Craig Elliffe and Jess Cameron "The Test for Tax Avoidance in New Zealand: A Judicial Sea Change" (2010) 16 NZBLQ 440 . 
with navigating the incredibly wide discretion of GAAR cases, specialist judges with a keen "sense of smell" are needed to appreciate fully the underlying policy. With avoidance cases comprising a significant percentage of tax cases, and those cases having such profound consequences for the development of the law and the New Zealand economy, the level of discretion afforded to judges in this area is a strong factor in support of specialisation.

Although the highly discretionary nature of tax law arguably provides strong support for specialisation, it can also exacerbate its dangers. A specialist court or panel concentrates the power to make substantial policy decisions, affecting thousands of taxpayers, in the hands of a small group of judges.

Specialist judges are more likely to harbour dogmatic policy biases, which may have more severe consequences in highly discretionary areas of law. Constant exposure to similar cases can reinforce a judge's views on a legal issue, lessening their ability to bring a fresh mind to new cases. Where any policy biases are favourable to the Commissioner, there is a greater risk that taxpayers could perceive a bias in highly discretionary decisions. Compared to a panel system, an external court would heighten these concerns regarding bias and idiosyncratic development of the law because judges on an external court would not decide other non-tax related cases and would lack a wider exposure to other legal issues.

\section{Factual issues and expert evidence}

Avoidance cases (as well as other types of tax cases) often involve difficult factual questions that demand specialisation. North P declared that the presence of avoidance is "ultimately a question of fact". ${ }^{159}$ To decide whether an arrangement is economically and commercially realistic, judges must be able to analyse factually complex financial arrangements.

Although specialist judges may cope best with the factual complexity of tax cases, they are particularly at risk of developing a narrow judicial perspective and pigeonholing certain fact situations that they are frequently exposed to. For instance, Sir Ivor Richardson has observed: ${ }^{160}$

On the factual side, if you listen to a diet of asset accretion cases, I suspect it is easy to become cynical of standard explanations of discrepancies between expenditures on living and capital assets and reported incomes

Yet, in highly factual decisions, it is particularly important that a judge bring a fresh mind to the particular case.

159 Elmiger v Commissioner of Inland Revenue [1967] NZLR 161 (CA) at 178.

160 Ivor Richardson "Observations from the Bench" (address to the NZ Society of Accountants 1994 Tax Conference, November 1994). 
The extent to which expert evidence may alleviate factual difficulties is relevant. Judges have been somewhat hostile, perhaps justifiably, ${ }^{161}$ to the inclusion of expert evidence in tax cases. In Penny $v$ Commissioner of Inland Revenue, ${ }^{162}$ the Commissioner disputed evidence on the basis that it related to questions of law, but for many tax issues, the boundary between law and fact is unclear. In the 2013 Court of Appeal avoidance case, Alesco v Commissioner of Inland Revenue, ${ }^{163}$ the Court acknowledged that expert evidence may assist the Court's understanding of factual context "where the impugned arrangement falls within a novel or sophisticated economic environment". ${ }^{164}$ Yet, the Court denied that expert evidence was necessary, stating that events at trial reflected "an increasing but unacceptable trend of resorting to experts to add to the armoury of advocacy". ${ }^{165}$ Overall, the factual problems associated with tax cases are exacerbated by a tendency of the judiciary to regard expert evidence as adversarial or simply "not particularly relevant". 166

\section{B Technical Complexity and Cohesiveness}

Legomsky's second criterion convincingly favours specialisation; tax is extremely technically complex. Specialists are better equipped to deal with this complexity and to produce more sound judgments because of their dedicated familiarity with tax laws. Identified specialist judges are also able to receive more targeted professional development and tend to hold a greater commitment to educating themselves in the specialised area. Legomsky outlines four factors suggesting technical complexity: size of the relevant legislation; organisational complexity; existence of a specialised terminology; and fact-finding that requires extra-legal knowledge. ${ }^{167}$

\section{Size of the legislation}

The sheer volume of statutes, ${ }^{168}$ regulations, cases, rulings, interpretations and rules is massive, and increasing in volume and effect each year. The Income Tax Act 2007 alone is some 3,852 pages

161 See generally Sir Ivor Richardson's discussion of the practical problems associated with expert economic evidence in "Economics and Law: The Courtroom Reality" (paper presented to New Zealand Law Society Seminar Economics and the Law: The Application of Economics in Legal Practice, Wellington, December 1990).

162 Penny v Commissioner of Inland Revenue [2009] 3 NZLR 523 (HC) at [53].

163 Alesco New Zealand v Commissioner of Inland Revenue [2013] NZCA 40, [2013] 2 NZLR 175.

164 At [96].

165 At [97].

166 Andrew McSmith "Expert Accounting Evidence and New Zealand Tax Litigation: A Research Note" (2007) 13(4) NZJTLP 565 at 582.

167 Legomsky, above n 36, at 24-26.

168 Legomsky, above n 36, at 24: "One view might be that technical complexity can arise from the sheer size of the pertinent legislation." 
and is New Zealand's largest piece of legislation. This does not indicate drafting failures; the Rewrite Advisory Panel had remarkable success in redrafting the Income Tax Act to enhance simplicity and readability. ${ }^{169}$ Lengthy tax legislation is not unique to New Zealand. The inherent features of tax law mean that other countries have all needed to develop myriad laws and regulations to define and capture taxes. As Prebble observes, the complexities of tax law often arise because of features innate to any tax system: unavoidably arbitrary geographical distinctions, artificialities in income years, and an unprincipled capital/revenue distinction, are all intractable problems. ${ }^{170}$ Accordingly, the voluminous complexity of tax law is unlikely to decrease, and this is not only necessary but also usually desirable when other values of a tax system, such as fairness and certainty, are incompatible with simplicity. ${ }^{171}$

\section{Organisational complexity}

Tax law involves a high degree of organisational complexity. The Income Tax Act is the only legislation routinely not drafted by the Parliamentary Counsel Office. This is partly in recognition of its technical complexity. ${ }^{172}$ The legislation takes on a unique organisational structure, with alphanumeric numbering and functional organisation. Rapid, technical developments take place outside of legislation in tax information bulletins, determinations, interpretation guidelines and statements, operational statements, product and public rulings, and standard practice statements.

In an increasingly global economy, the organisational complexity rises because of the addition of double tax treaties or provisions geared towards cross-border arrangements. It is likely that even more major conceptual developments will come in the next few decades because the complexity of tax law is inextricably linked to the rapidly changing international economy.

169 Ivor Richardson "Simplicity in Legislative Drafting and Rewriting Tax Legislation" (2012) 43 VUWLR 517 at 525-527; and Maryann Richardson and Adrian Sawyer "Complexity in the Expression of New Zealand's Tax Laws: An Empirical Analysis" (1997) 14 Aust Tax F 325 at 352-354.

170 John Prebble "Why is tax law incomprehensible?" (1994) BTR 380-393; John Prebble "Can Income Tax Law be Simplified?" (1996) 2 NZJTLP 187; and John Prebble "Income Taxation: A Structure Built on Sand" (2002) 24 SLR 301.

171 For instance, the United Kingdom Tax Law Rewrite Project Team has defended the complexity of tax legislation by pointing out that the complexity furthers the interests of fairness and is necessary to keep apace with economic developments: "The fact that we in the UK have some 6,000 pages of primary tax legislation is not a reflection of the prolixity of successive Parliamentary drafters, rather it reflects the choices the UK has made over more than 150 years to try to ensure the burden of taxation falls equitably in an increasingly complex and diverse world": Steve Matheson, Geoffrey Sellers, and Neil Munro "The Audience for Tax Legislation - Is It Different From That for Other Legislation and Should It Be Considered To Be the Same for All Sections or Parts?" (1997) 3 NZJTLP 178 at 181.

172 But see Prebble and Prebble, who suggest that the drafting position simply arose "as a result of historical accident" because the IRD were undertaking redrafting at a time when the Parliamentary Counsel Office was under-resourced: Prebble and Prebble, above n 85, at 244. 


\section{Specialised terminology and extra-legal knowledge}

Specialised terminology does not contribute to tax's complexity because most technical terms are obvious to a non-expert or explicable by counsel. However, the fact-finding endeavour of tax law often requires extra-legal knowledge from accounting or economics fields. Legislation often refers to accounting standards or practices, and an understanding of so-called "economic realities" is central to the application of the GAAR. More fundamentally, the lack of a basic definition of "income" has necessitated the incorporation of accounting and economic principles. ${ }^{173}$

\section{Drawbacks to technical expertise}

A mastery of the technical complexity of tax law may have drawbacks. The risk of judicial activism may be greater with specialist judges because specialists with expertise, through constant work in one field, tend to feel greater confidence in their judgment than their generalist counterparts. ${ }^{174}$ Judges are more inclined to making sweeping policy decisions, when they may not be best placed to anticipate the fiscal (or other) consequences without access to full parliamentary resources.

\section{A crisis of confidence?}

Although the complexity of tax law is relatively undoubted, the extent to which the New Zealand judiciary is capable of dealing with this complexity is contested. In a controversial article, Tony Molloy QC criticised the judiciary's institutional competence in dealing with complex cases, stating: ${ }^{175}$

... the courts produce a plethora of judgments from which it is clear that counsel, or the judge-and frequently both counsel and the judge — have been trying to grapple with areas of the law beyond the level of their skill or experience.

Molloy's comments in this article, along with a tirade of statements to the National Business Review, were widely criticised. ${ }^{176}$ Yet, Molloy's sentiments are not entirely isolated. High profile

173 Ivor Richardson "The Impact and Influence of Accounting and Economic Principles on Taxation Law" (1998) 4 NZJTLP 18; and Kevin Holmes "Should Accountants Determine How Much Tax We Pay?: International Accounting Standards vs. Taxable Income and Capital Gains" (Professorial Inaugural Lecture, Victoria University of Wellington, Wellington, 25 September 2007).

174 Baum, above n 31, at 35 .

175 Molloy, above n 4, at 20.

176 Molloy's comments included that "the public of New Zealand is being shafted by the manner in which the judiciary is being deployed", suggestions that judges were "flouting their oath", and that the justice system was "fraudulent" because of the lack of specialisation: Rod Vaughan "New Zealanders shafted by fraudulent justice system, says top QC" The National Business Review (online ed, New Zealand, 29 August 2012). Attorney-General Chris Finlayson condemned the comments as "a vulgar, crude and intemperate attack on our judicial system": Jock Anderson "Outraged Finlayson says judge-critic Tony Molloy should quit QC rank" The National Business Review (online ed, New Zealand, 31 August 2012). The National Standards 
barrister Anthony Grant employed similarly strong language in claiming that "the age of the generalist has passed... [L]itigants know this and are reluctant to submit a dispute in a specialised area of law to a Judge who has no known competency in that area of law."177

Statements such as these have contributed to what the Law Commission described as the "awkward question of whether there is a want of confidence in some High Court judges, particularly in the commercial law area". ${ }^{178}$ Criticisms of the judiciary's technical competence and the decline in tax cases support the idea that there is a crisis of confidence. However, the Law Commission has noted several objective measures of the quality of generalist High Court decisions. The Commission cited the numerous examples of overseas cases citing New Zealand judgments approvingly, ${ }^{179}$ and the 7,500 foreign trust registrations in New Zealand in October 2006-November 2012, ${ }^{180}$ as evidence that overseas institutions respected New Zealand as a jurisdiction for business affairs, contrary to the notion that confidence in the New Zealand jurisdiction is lacking. The report cited the collective submission of New Zealand judges, which remarks that "there does not seem to be any evidence that appeals from generalist judges are more likely to be overturned on appeal". ${ }^{181}$ It seems that the perception and anecdotal evidence of the competence of the judiciary, particularly as expressed by many lawyers, is not objectively supported.

Although the views expressed by actors in the tax system vary widely, there is a perceptible division between judges and lawyers in the specialisation debate. ${ }^{182}$ It may be that tax lawyers, who often focus solely on tax law, are more inclined to rally for what they perceive to be improvements to the tax system that they exclusively deal with. Those who work wholly in tax law have interests in privileging the resolution of tax disputes over other cases, and have a particular interest in disputes being settled at court, rather than resolution by the disputes system. On the other hand, judges may be better positioned to holistically gauge the consequences of specialisation for the justice system overall. It is improper to dismiss the legitimacy of the insights that lawyers offer as being purely myopic or self-interested, but the interests of different stakeholders in the wider court system must be considered when referring to the specialisation debate.

Committee of the Law Society ordered Molloy to pay \$1,000: Notice of Determination by the National Standards Committee (NSC) (Determination 6446, December 2013).

177 Anthony Grant "Courts - Is the High Court's Civil Jurisdiction in 'a Death Spiral' (Part 3)" Anthony Grant: Barrister <www.anthonygrant.com>.

178 Law Commission, above n 2, at 113.

179 At 113

180 At 114

181 At 103

182 At 103-106. 


\section{Cohesion}

A cohesive area of law containing substantial interrelationship can benefit from specialisation because specialist judges have a greater appreciation for the overall scheme of the law and can decide cases without creating unintended consequences for other cases within that branch of law. The complexity of tax law prevents its classification as "cohesive", which counts against specialisation. Specialisation may also impinge on the overall cohesion and accessibility of the court framework. Damage to the organisation of the court framework may create difficulties for litigants to determine where a claim lies and a panel within the High Court could internally fragment the Court. As a byproduct of this fragmentation, the valuable collegiality amongst High Court judges may be eroded, particularly if divisions are seen as elitist or insular. ${ }^{183}$

\section{Dynamism}

The dynamism of tax law favours specialisation because specialist judges' commitment to following developments best enables them to keep apace of the law.

Although tax law is subject to rapid changes, its existence as a primary area of law is longstanding. Unlike the Administrative Division, which became redundant as High Court judges became more conversant with public law matters, tax law is already mainstreamed in the judicial consciousness.

Tax law is dynamic for several reasons. First, it is an area that is aggressively tested by taxpayers, with Harley suggesting that: ${ }^{184}$

... as taxpayers find new ways of acting just outside the boundary of what is taxable, so the government

changes the definition of what is taxable to account for the new challenge. This is why there are so many

Income Tax Amendment Acts each year and why tax law becomes so complicated.

Taxpayers match each move by the Commissioner with an increasingly sophisticated arrangement, precipitating the enactment of more laws. ${ }^{185}$

Tax law is exceptionally dynamic because of its political exposure. The 1993 New Zealand Law Conference discussed how "tax is the classic area in which the law and politics interact on a daily

183 The New Zealand Bar Association "Submission to the Law Commission on the Review of the Judicature Act 1908" as cited in Law Commission, above n 2, at 105.

184 Geoff Harley "Tax and Law" [2002] NZLJ 305 at 305.

185 See also James R Hines Jr "On the Timeliness of Tax Reform" (2004) 88 Journal of Public Economics 1043. 
basis". ${ }^{186}$ Political parties campaign on tax reform proposals and the tax system is subject to frequent reforms in service of political agendas. ${ }^{187}$

Sir Ivor Richardson attributed the dynamism of tax law to the economic and social objectives it serves, concluding that "there is no other area of our law which is so subject to constant review and change". ${ }^{188}$ As well as substantive changes to the law, attitudes towards taxation and compliance can shift and alter the volume of cases. The former President of the Australian Administrative Appeals Tribunal noted that "fashions in tax avoidance" could cause significant fluctuations in the volume of cases coming before the courts. 189

Any specialisation would need to be flexible enough to withstand a changing caseload, according to political, policy and compliance changes. Tax panels are preferable to independent courts, because they cope better with fluctuating caseloads by having judges sit on other cases when there is reduced demand for tax litigation. Ultimately, generalist courts would allow for the greatest flexibility.

\section{Degree of Isolation}

The degree of isolation of an area of law is a double-edged sword, at times favouring specialisation and at others favouring generalism. Legomsky identifies discreteness and uniqueness as the properties of isolation.

Tax law is discrete, even though cases often involve issues that are equally classifiable as, inter alia, company law, property law, or criminal law. The discreteness of tax can be narrowing the perspectives of specialist judges. French J has spoken out against specialist courts stating that: ${ }^{190}$

One of the great strengths of the law is the facility it offers to cross-fertilise concepts and approaches from one area to another. Specialisation leads to intellectual inbreeding and risks the development of excessively comfortable relationships between judges and members of the relevant specialist bar.

Perhaps the scarce evidence of the cross-fertilisation of other legal concepts into tax law signals that it is already isolated and parochial, when this should not necessarily be the case. It may be that

186 Ivor Richardson and others "Tax Law: How Can the System Generate the Cash Needs of Government, and Still be Fair to the Ordinary Taxpayer?"(panel discussion at the 1993 New Zealand Law Conference, Wellington, March 1993) at 200.

187 Sawyer claims that "tax policy and politics go hand in hand" and observes that the influence of consultation in the generic tax policy process pales in comparison to the will of politicians in tax policy formulation: Adrian Sawyer "Reviewing Tax Policy Development in New Zealand: Lessons from a Delicate Balancing of 'Law and Politics' (2013) 28 ATF 401 at 402. See also Paul Goldsmith We Won, You Lost, Eat That!: A Political History of Tax in New Zealand Since 1840 (David Ling Publishing Limited, 2008).

188 Ivor Richardson "Appellate Court Responsibilities and Tax Avoidance" (1985) 2 ATF 3 at 3.

189 Downes, above n 132.

190 Jeremy Curthoys "In Conversation with Justice Robert French" (2002) 50 IPF 6 at 8. 
the lack of connections with other areas of law is not due to the nature of tax law, but is because of an already blinkered perspective of tax practitioners or judges. Caron suggests that the misperception that tax law is a self-contained body of law has "impaired the development of tax law by ignoring insights from other areas of law that should inform the tax debate". ${ }^{191}$ In the Australian context, Gordon $\mathrm{J}$ has remarked: "Another effect of specialisation and myopia in the tax profession is the inability, failure or refusal to embrace the particular facts of a problem." 192 Gordon J pointed to Aid/Watch Incorporated $v$ Commissioner of Taxation, ${ }^{193}$ as an example of a case with a pronounced need to think "outside of the tax sphere"194 and look to the general law of charities to determine whether the political activities of a taxpayer institution defeated its charitable characterisation, despite the case's classification as a tax case. ${ }^{195}$ The New Zealand Supreme Court did not characterise the materially similar case of Re Greenpeace of New Zealand Incorporated ${ }^{196}$ as a tax case, ${ }^{197}$ demonstrating the artificiality of sectioning off an area of law. Judge Barber commented that in cases before the TRA, "all sorts of legal problems only indirectly related to the tax situation arise", such as commercial, trust, or criminal issues. ${ }^{198}$ In the many cases that are not strictly tax-specific, a specialist tax judge is no better equipped than a generalist is.

Tax law may be described as unique because analogies are unlikely to be drawn with the resolution or reasoning of cases in other fields. Tax law is primarily statute based, and it has developed unique processes of statutory interpretation, ${ }^{199}$ where orthodox, traditional methods of interpretation have

191 Paul Caron "Tax Myopia, Or Mamas Don't Let Your Babies Grow Up To Be Tax Lawyers" (1994) 13 Va Tax Rev 517 at 518.

192 Michelle Gordon "Tax Is More Than Numbers - But It Is Also More Than Tax: The Interrelationship between Tax Law and Other Areas Of Law, and The Consequences On Teaching, Drafting and Interpreting Tax Laws" (speech to the 23rd Australasian Tax Teachers Association Conference, Melbourne, January 2011) at 2.

193 Aid/Watch Inc v Federal Commissioner of Taxation [2010] HCA 42, (2010) 241 CLR 539.

194 Gordon, above n 192, at 2.

195 The case was brought against the Commissioner and classified as a tax case, even though "the dispute [was] occasioned not by the terms of the revenue legislation ... but by the content of the general law respecting charitable purposes": Aid/Watch Inc v Federal Commissioner of Taxation, above n 193, at [27].

196 Re Greenpeace of New Zealand Incorporated [2014] NZSC 105, [2015] 1 NZLR 169.

197 In New Zealand, the case was not referred to by the Supreme Court as a tax case, even though the Court acknowledged that the principal advantage of charitable registration is tax relief: at [1].

198 Barber, above n 84, at 2.

199 See generally Eugen Trombitas "Statutory Interpretation and Tax Avoidance" [2010] NZLJ 428. 
been inappropriate. ${ }^{200}$ However, unique approaches to statutory interpretation have been criticised by the likes of Kirby J, who stated:201

It is hubris ... to consider that "their Act" is special and distinct from general movements in statutory

construction which have been such a marked feature of our legal system.

Again, it may be that tax law itself is not isolated, but practitioners of tax law hold it in isolation.

Whatever the causes of the isolation, it gives rise to an insensitivity of generalist judges to tax implications of their judgments, whereby a judge's decision in an ostensibly unrelated case can have a ripple effect on tax law. Isolating tax law further by removing it from the general court system or from other generalist judges, heightens this risk.

\section{E Repetition}

Areas of law involving a high degree of repetition are more likely to warrant specialisation because they can maximise efficiency. Rather than requiring many judges to become familiar with a repetitive case model, specialisation targets the initial education at a smaller pool of judges. Repetitive cases intensify the need for consistency within an area of law, and consistency is best served by judicial specialisation because specialisation brings familiarity and exposes a case to fewer conflicting adjudicators. $^{202}$

The presence of repetitive cases may pose problems for judicial recruitment, when the role attracts many judges because of the diversity it offers. It is difficult to predict whether tax judicial specialisation would improve or impair recruitment. The wide range of work of generalist judges may be attractive to potential judges. ${ }^{203}$ Perhaps it would even come as a relief to many candidates to know they would not hear tax cases. ${ }^{204}$ On the other hand, an opportunity to delve further into specialisation is appealing to judges with a strong interest in that area.

200 For instance, because the Income Tax Act's purposes expressly include the purpose of imposing tax, a purely purposive approach may often be inappropriately stacked in favour of the Commissioner because the interpretation that prevails would be the interpretation that imposes the most tax. See: Income Tax Act 2007, s AA1(a); and Commissioner of Inland Revenue v International Importing Ltd [1972] NZLR 1095 (CA).

201 Federal Commissioner of Taxation v Ryan (2000) 201 CLR 109 at [84]. See also Michael Kirby "Hubris Contained: Why a Separate Australian Tax Court Should Be Rejected" (speech to the 23rd Challis Taxation Discussion Group, Sydney, 3 August 2007).

202 Legomsky, above n 36, at 27.

203 Law Commission, above n 2, at 103.

204 Former Taxation Review Authority, Judge Barber, attributed the backlog of tax cases in the High Court in the mid-1980s to the fact that "if you speak to any of the High Court Judges, they will tell you that they don't much like handling tax cases": Riley and others, above n 60, at 475. 
However, although avoidance cases dominate substantive tax litigation, the remaining cases often sprawl a range of technical or procedural issues, ${ }^{205}$ undermining the characterisation of tax law as an overly repetitive branch of law. Even within avoidance cases, there is minimal repetition and different arrangements require separate factual examination.

\section{F Clannishness}

The clannishness of lawyers, government officials and experts within the tax field also favours generalism. Most law firms have a dedicated tax team and lawyers rarely move in and out of a tax specialisation because of the significant time taken to build expertise. This clannishness can increase the chances of perceptions of bias because of the familiarity of adjudicators and other actors in the system.

The tax community's clannishness may also give rise to a greater risk of complacency and a reduction in innovative jurisprudence because of the minimal exposure to outside judicial thinking. A fresh perspective is necessary to question assumptions or settled modes of judicial thinking. New Zealand's comparatively small legal population makes clannishness more troubling. From the outset, a handful of law professors will teach most New Zealand tax lawyers, who then progress through the insular tax community, attending tax-specific conferences, undergoing professional development and networking. There is a self-selection bias before law students even commence their education, with Caron stating: "Tax courses are perceived to be reserved for...'tax geeks' - accountant-types who carry calculators and plastic pocket-protectors for their multi-color array of pens." ${ }^{206}$ Specialist judges are likely to come from this small, closed tax community and may consequently develop a narrow judicial perspective.

Another consequence of clannishness is an exposure to manipulation. Glazebrook $\mathbf{J}$ suggests: "A major risk of specialization is that judicial objectivity may be lost due to actors in the sphere becoming too familiar, and judges thus becoming vulnerable to interest group manipulation. "207 Interest groups need not spread their efforts across a general bench in the hopes of influencing decision making. This leaves few tax judges more susceptible to capture or pressure by interested parties.

Greater tax judiciary specialisation may also damage the representativeness of the bench because the profession often lacks diversity. ${ }^{208}$ Worldwide, there is a concentration of men in the tax

205 Judge Barber has commented on the broad range of cases that came before the Taxation Review Authority, stating: "Even from the general description of cases noted in the memorandum, it can be seen that the typecoverage is quite extensive and all sorts of legal problems only indirectly related to the tax situation arise": Barber, above n 84, at 2.

206 Caron, above n 191, at 519

207 Glazebrook, above n 33, at 538.

208 The record of appointments to the Taxation Review Authority reinforces the existence of this problem, with only one female tax judge in the history of the Authority. 
profession, ${ }^{209}$ which risks exacerbating the unsatisfactory gender diversity of the judiciary. ${ }^{210}$ New Zealand is unexceptional; lawyers who spend over 50 per cent of their time on tax law fall in a 39:61 female to male ratio. ${ }^{211}$ Indeed, there is a question of whether the small tax community would provide an adequate (let alone diverse) pool of judicial candidates. Judging is, in itself, a legal specialisation, ${ }^{212}$ with only a small number of lawyers possessing the necessary qualifications and attributes. Limiting the potential pool to a single area of law may prove difficult in terms of recruitment.

Despite tax law's clannishness, there have been few applications for recusal for judges of the Taxation Review Authority, perhaps suggesting that arguments relying on perceptions of bias are overstated, since the existence of a single tax adjudicator has not translated to a significant number of recusal applications. Mr John Russell made the only recusal application to an Authority, Judge Barber, who refused. ${ }^{213}$ Mr Russell alleged that Judge Barber was biased because he had consistently held against Mr Russell in 65 cases between 1989 and 2005, ${ }^{214}$ which involved the "Russell Template", a tax template that Mr Russell designed. Mr Russell argued that Judge Barber had "formed very firm views concerning the template". ${ }^{215}$ It was unnecessary to decide at the High Court or Court of Appeal whether there was apparent bias because Wylie $\mathrm{J}$ reheard the substantive case at the High Court and there was no suggestion that he was biased. Although this case represents an isolated event of recusal application, it demonstrates how the risk of apparent bias can flow from a single specialised judge forming fixed views as a result of hearing the same types of cases.

209 Ulrike Shultz and Gisela Shaw Comparative Sociology of Women Lawyers: The "Feminization" of the Legal Profession (Hart Publishing, Oregon, 2003) at 346.

210 Law Commission, above n 14, at 27. See also Susan Glazebrook "Looking Through the Glass: Gender Inequality at the Senior Levels of New Zealand's Legal Profession" (speech to the annual "Chapman Tripp Women in Law" event, Wellington, 16 September 2010).

211 New Zealand Law Society/Momentum Legal Salary Survey 2011 (2011) at 16. The only areas of law where men featured more dominantly than in tax were lending activities, arbitration, banking and finance, company/commercial, civil litigation, immigration and property.

212 Law Commission, above n 2, at 103.

213 Russell v Commissioner of Inland Revenue TRA 003/03 Decision No 10/2005, 27 July 2005.

214 The Taxation Review Authority heard 82 cases related to Mr Russell since 1989. Sixty five of those cases were heard by Judge Barber: Russell v Taxation Review Authority (2009) 24 NZTC 23,284 (HC) at [1].

215 Russell v Commissioner of Inland Revenue, above n 213, at [9]. 


\section{G Peculiar Importance of Consistency}

Legomsky argues that specialisation helps ensure the law's internal consistency. This is important in relation to tax law because fairness is an essential aim of the income tax system; ${ }^{216}$ taxpayers who are similarly placed should be taxed consistently. Compliance is often dependent on perceptions of fairness. $^{217}$

Recently, tax avoidance has begun to attract the wider public's attention, with increased political and media coverage. The IRD's report on the taxation of multinational companies noted: "Media comment around the world has focused on the unfairness of the low levels of tax paid by some multinationals", 218 which suggests that the adjudication of tax disputes may already be perceived to favour large multinational parties.

Taxpayers are often indirectly in competition, heightening the need for consistent decision making to avoid unfair tax advantages for some taxpayers over their competitors. Where competing taxpayers structure their affairs identically, decisions must be consistent between taxpayers.

In a small country like New Zealand, the difference between specialist and generalist adjudicators may be minimal. In commenting on the decisions coming from the TRA, Harley suggested that there is "bound to be inconsistency" with five Authorities deciding cases with similar issues, but that the inconsistency is no greater than for some 24 to 26 High Court judges at the Court of Appeal. ${ }^{219}$ If a mere five Authorities is enough to create inconsistency in the law, then a tax panel is unlikely to remedy this problem.

\section{H Degree of Controversy}

Legomsky argues that controversial subject-matter favours generalism because controversy heightens the problems associated with concentrated judicial power and the risk of apparent bias. The controversy of tax judgments arises for several reasons.

First, the large amount of money involved and the far-reaching consequences of tax law mean that decisions are of considerable public interest. Sir Ivor Richardson affirms the significance of tax law,

216 Victoria University of Wellington Tax Working Group A Tax System for New Zealand's Future (Victoria University of Wellington Centre for Accounting, Governance and Taxation Research, January 2010) at 9-10.

217 Natrah Saad "Fairness Perceptions and Compliance Behaviour: The New Zealand Evidence" (2011) 17 NZJTLP 33.

218 Inland Revenue Department Taxation of Multinational Companies (Tax Policy Report, T2012/3250; PAD2012/268, December 2012) at 10.

219 Geoff Harley "Tax Law: How Can the System Generate the Cash Needs of Government, and Still be Fair to the Ordinary Taxpayer?" (panel discussion at the 1993 New Zealand Law Conference, Wellington, March 1993 ) at 200 at 209. 
asserting: "There is no other legislation which is so far reaching and pervasive and which touches human activities at so many points."220

Highly discretionary decisions, such as those in anti-avoidance cases, tend to be the most controversial because the risk of policy-making or judicial activism tends to be the most clearly exhibited in this context. On the topic of tax avoidance, Keating asks: ${ }^{221}$

What is it about tax avoidance that causes so much controversy? No other single provision of the Income

Tax Act is so commonly litigated. No other aspect of tax generates as much heated debate in both tax

practice and academic circles.

Tax cases also create a high degree of controversy because litigation is effectively between the individual and the government, ${ }^{222}$ with the result that the resolution of tax cases is of significant public importance. McKay suggests that taxation is a fundamental element of the relationship between the state and the citizen, arguing: 223

Such is the impact of taxation, so vital is it to the character, the quality, of both our day-to-day lives as individuals, and the overall social face of our society, that it seems to me to be a matter of constitutional significance.

The government's interest in taxation is immense, with over $\$ 53.8$ billion collected in the 2012/2013 tax year. ${ }^{224}$ The Commissioner also arguably benefits from a power imbalance in litigation, ${ }^{225}$ having access to the full resources of the state. This intensifies the need for public justice in tax cases and suggests that an ordinary court of record ought to hear cases because it is more likely to be open, accessible and transparent to most citizens. Constitutionally, the judiciary is one of the few, limited checks on Parliament's otherwise unrestrained power to impose tax. Sir Ivor Richardson has noted that over time the judiciary has adopted a less protective role in respect of individual

220 Richardson, above n 188 , at 3.

221 Keating, above n 150, at 115.

222 The Solicitor-General, in his or her capacity as Chief Executive of the Crown Law Office, is ultimately responsible for the representation of the Commissioner of Inland Revenue in litigation: see generally "Protocols Between the Solicitor-General And Commissioner of Inland Revenue" (29 July 2009) Inland Revenue <www.ird.govt.nz>.

223 Lindsay McKay "Taxation and the Constitution" (1985) 15 VUWLR 53 at 58.

224 Inland Revenue Annual Report 2013 (Wellington) 2013 at 7.

225 It has been argued in the Australian context that individual taxpayers in particular can suffer from an unfavourable imbalance in power: Binh Tran-Nam and Michael Walpole "Independent Tax Dispute Resolution and Social Justice in Australia" (2012) 35 UNSWLJ 470 at 475. 
taxpayers against the executive. ${ }^{226}$ This shift may mean that the court system affords the taxpayer even less protection from the state's whims, intensifying the controversy of decisions. In many other civil disputes, litigants have a wider range of dispute resolution available to them outside the court system, such as arbitration or mediation. The need for the court process to limit controversy and, in turn, be respected as an independent and reputable forum, is greater because tax litigants do not have the same choice of forum and degree of voluntariness towards litigation.

Tax could also be described as a subject-matter with "high emotional content" because of the taking of property that it involves. ${ }^{227}$ Certainly, some regard taxation as an extraction of private wealth and a deeply intrusive power of the state. Judge Barber observes that the "harrowing" process prior to a case reaching court can add to the emotional content of tax cases, resulting in an "air of great tension and ill feeling between the parties" that strengthens the need for an undoubtedly independent adjudicator. ${ }^{228}$ Indeed, he recounts instances of taxpayers weeping inconsolably upon the realisation that they were finally "actually in an independent judicial forum". ${ }^{229}$ Most of the countries surveyed in Part IV have additional measures in place for the protection of taxpayers, such as a dedicated tax ombudsman in Australia or a "taxpayer bill of rights" in the United States. ${ }^{230}$ There is a risk that, absent these checks, a small tax court with a greater susceptibility to bias or corruption may corner taxpayers, leaving them with limited recourse. ${ }^{231}$ Even where appeal is available, appellate courts remain bound by the tax court's findings of facts, which may be of little consolation for litigants in fact-centric tax decisions.

Tax avoidance scholarship has frequently engaged with questions of the morality of tax avoidance. With this degree of emotional content, a judge's particular persuasion on an issue is even more likely to enter into that judge's decision making, and may lead to the development of a bias. The exposure of many taxpayer companies to a great deal of moral and ethical scrutiny ${ }^{232}$ also means that the

226 Ivor Richardson "Attitudes to Income Tax Avoidance" (inaugural address delivered before Victoria University of Wellington, 18 April 1967) at 16.

227 Legomsky, above n 36, at 27.

228 Riley and others, above $\mathrm{n} 60$, at 475.

229 At 475

230 See generally Adrian Sawyer "A Comparison of New Zealand Taxpayers' Rights with Selected Civil Law and Common Law Countries - Have New Zealand Taxpayers Been 'Short-Changed'?" (1999) 32 Vand J Transnat'l L 1345.

231 The Government is looking to establish a conduct complaints process, which may help to boost the accountability of judicial officers in the Taxation Review Authority: Cabinet Social Policy Committee Paper, above $\mathrm{n} 50$, at 6 .

232 Keating observes that allegations of tax avoidance carry a "significant reputational dimension": Keating, above $\mathrm{n} 150$, at 133 . 
decisions are more likely to be highly controversial and have an emotional impact, heightening the need for public justice in the ordinary courts.

However, the controversy of tax cases persists, even when the general courts decide them. Many commentators have labelled recent decisions, particularly in avoidance cases, as "controversial" and have been critical of the Commissioner's success rate. ${ }^{233}$ Coleman notes that the successful streak of appeals by taxpayers in the 1990s has now ended and has been replaced by a string of successes for the Commissioner, emboldening her to take "...a more and more aggressive stand in litigation". ${ }^{234}$ In a series of interviews with tax lawyers, accountants, academics and former IRD investigators, there was some evidence of a feeling that the generalist judiciary was increasingly likely to side with the Commissioner's position, with the results suggesting: "The participants felt that there had been a shift in judicial attitude when interpreting the general anti-avoidance provision. Further, this shift has swung the pendulum the way of the Commissioner."235

Greater judicial specialisation may send a message to taxpayers that the judiciary takes these controversial matters seriously. Greater judicial specialisation could have an important symbolic value in respect of tax law, by establishing that the resolution of tax disputes has a special status in New Zealand. This may encourage greater investment in New Zealand as a business jurisdiction, ${ }^{236}$ as well as greater compliance. The opposite possibility exists; taking tax outside the mainstream court system might simply create a perception of tax matters' relegation and confine taxpayers to a court of lower standing, depending on the specialist court's strength and resourcing.

Additionally, a differing perception of the status of a court may also influence the court's ability to recruit judges, ${ }^{237}$ as occurred in relation to Canada's former Board of Review. The Law Commission noted that in a submission signed off by the senior courts' Heads of Bench it was suggested that "in accepting a High Court warrant, a judge necessarily 'gives up' a career where that person will have some real standing, and in most cases a better financial return than that provided to the judiciary". In light of that, recruitment may become even more difficult if candidates perceive specialist courts to be less prestigious. ${ }^{238}$

233 Hamish Fletcher "Tax Ruling Alarming - Expert" The New Zealand Herald (online ed, Auckland, 6 March 2013).

234 James Coleman "Tax Update" [2014] NZLJ 43 at 43.

235 Richard Bracefield and others "Perspectives and Implications of the Supreme Court ruling in Penny: Evidence of an Expectations Gap? (2013) 19 NZJTLP 51 at 56.

236 The Law Commission acknowledged that "how things present themselves to the business sector is an important intangible element": Law Commission, above n 2, at 114.

237 Markus Zimmer "Overview of Specialized Courts" (2009) 2 International Journal for Court Administration 46 at 47.

238 Law Commission, above n 2, at 103. 


\section{Logistics: Volume, Time and Geographic Distribution}

Even though many of these criteria point towards specialisation, the logistics produce the most fatal objection. The Law Commission has acknowledged: "It would not be sensible for any jurisdiction to introduce change into a quality generalist jurisdiction unless the need to do so can be properly demonstrated." This need is not yet demonstrated. Much of the efficiency gain from a specialised judicial system relies on a steady stream of cases, which the small jurisdiction of New Zealand would fail to supply. ${ }^{239}$ Additionally, specialisation renders the court system less responsive to fluctuations in the volume of cases in particular areas. Glazebrook $\mathbf{J}$ dismissed the possibility of an independent tax court on logistical grounds: $:^{240}$

\footnotetext{
In a jurisdiction as small as New Zealand ... the creation of a separate court dealing with all tax cases is not really an option, particularly with the decline in tax cases being brought before the courts. Even in its heyday, the Taxation Review Authority could not support more than two judges.
}

There are few empirical studies of the volume of tax litigation, but many commentators echo Glazebrook's J view that the number of tax cases is decreasing steadily. The Ministry of Justice's review of Wellington and Auckland High Court registries in 2010 put tax law at just 3.8 per cent of the total sample of cases. ${ }^{241}$ However, in the Bar Association's submissions they noted that "many of the countries that are actually embracing specialisation are relatively small, and that on the international experience size alone is not a significant inhibiting factor". ${ }^{242}$ This claim is not borne out by surveys of similarly sized countries; the few specialist tax courts or panels in countries of comparable size to New Zealand is compelling evidence of the unfeasibility of further specialisation. ${ }^{243}$

As well as the number of tax disputes, the type of disputes is relevant to any proposals for specialisation. Glazebrook J observed an increasing trend towards procedural disputes between 1996 and 2008 because of "teething difficulties" caused by procedures introduced in 1996. ${ }^{244}$ Substantive decisions heighten the benefits of specialisation because they are more likely to engage the judge's

239 This was the conclusion of the Law Commission in Delivering Justice for All: A Vision for New Zealand Courts and Tribunals, above n 12, at 263: "Given the size of the New Zealand jurisdiction and the number of judges in the High Court, we do not believe that the system can have specialist judges to the exclusion of work in the broad general jurisdiction."

240 Glazebrook, above n 86, at 21.

241 Law Commission, above n 2, at 108-112.

242 The New Zealand Bar Association "Submission to the Law Commission on the Review of the Judicature Act 1908 " as cited in Law Commission, above n 2, at 105.

243 See Appendix 4.

244 Susan Glazebrook "Taxation Disputes in New Zealand" (paper presented to Australasian Tax Teachers Association (ATTA) Conference, Auckland, January 2013) at 2. See also Young, above n 83, at 7-12. 
specialist skill set and knowledge. The difference that judicial specialisation makes to the determination of procedural issues, judicial review decisions or enforcement decisions, is minimal. However, Glazebrook $\mathbf{J}$ suggests that the rise in procedural issues has settled, observing that in the 2008-2013 period the number of procedural cases in the High Court had dropped to some five cases per year, compared to 14 procedural cases in the 2003-2008 period. ${ }^{245}$ The "most important tax cases" before the Supreme Court between its introduction in 2003 and 2013 have featured a more balanced ratio between procedural and substantive issues; of the 12 tax cases before the Supreme Court, five involved procedural issues and the remainder involved tax avoidance or evasion and goods and services tax. ${ }^{246}$ Brown suggests that a reduction of procedural cases is not so obvious, arguing that "relatively few of the cases involving Inland Revenue relate to substantive tax disputes (for example, disputes concerning the application of substantive taxing provisions)". 247

Most commentators seem to agree that, at least for the substantive cases, tax avoidance is a dominant issue. Keating looks broadly at IRD's attitude towards general anti-avoidance provisions, finding that between 2004 and 2010, the Department's investigators sought approval to invoke either the GAAR or the anti-avoidance rule in s 76 of the Goods and Services Tax Act 1985804 times, with approval granted in 724 instances. Keating concludes that tax avoidance is a "major feature of the New Zealand tax landscape" that consumes a "disproportionate amount of the resources of Inland Revenue, taxpayers, the courts and practitioners". ${ }^{248}$ This has implication for the merits of specialisation. The controversy and discretion that are strongly associated with general anti-avoidance rules are heightened in these cases, militating against specialisation.

Additionally, the "price" of administering a specialist court or panel is not simply figurative. A separate court "does not come cheap", ${ }^{249}$ and although a panel would better utilise existing facilities and court systems, it would still involve additional administrative and managerial costs that are unlikely to be offset by any efficiency gains. New Zealand's geographic dispersal would further complicate the logistics of specialisation. Legomsky notes: "A small pie is inconvenient enough, but having to carve it into even smaller segments exacerbates the problem." ${ }^{250}$ Adjudicating a small number of tax cases across New Zealand's major populations, presumably with a circuit system, ${ }^{251}$

245 Glazebrook, above n 86, at 3.

246 Susan Glazebrook "Taxation Disputes in New Zealand" (paper presented to Australasian Tax Teachers Association (ATTA) Conference, Auckland, January 2013) at 3.

247 Brown, above n 91, at 4.

248 Keating, above n 150, at 115-116.

249 Law Commission, above n 14, at 70.

250 Legomsky, above n 36, at 31.

251 This would follow the practice of the Taxation Review Authority, which is based in Wellington, but travels in circuit around New Zealand: Prebble and Prebble, above n 85, at 248. 
would be costly to administer and can lead to certain cities with backlogs of cases and others with an idle jurisdiction.

Ultimately, the tax caseload is insufficient to justify further specialisation, and of the cases that do reach court, the procedural nature of many cases would not reap the full benefits of specialisation. Although these problems fall under a single criterion, the logistical problems associated with an inadequate caseload are fatal to the implementation of tax specialisation.

\section{J Unique Procedural Needs}

Tax law does not feature particularly unique procedural needs. Already, the TRA has relaxed rules of evidence that allow it to receive any documents or information that assist with the effective dealing of the inquiry. ${ }^{252}$ Judge Barber described the TRA as a "slightly relaxed forum" that is "supposed to be trying to put the taxpayer a little bit at ease". ${ }^{253}$ The procedural rules are also relaxed for cases that fall under pt 8 of the Tax Administration Act 1994 that the High Court hears. ${ }^{254}$ An advantage of the Authority's status as a tribunal is the room it has to develop fast-tracking or informal procedures in the future (as in Australia and Canada), which is a possibility that the ossified High Court Rules limit. $^{255}$

Typically, the taxpayers who take tax cases to court tend to be large companies represented by skilled and experienced advocates who are comfortable with formal court procedures. The high quality of advocacy in tax cases suggests that judges do not need to take a specialised and more active role in the exposition of a case. ${ }^{256}$

\section{K Special Need for Prompt Resolution}

A need for prompt resolution suggests that specialisation is desirable. Specialists are able to deal with cases more rapidly because less preparation and research around basic principles is necessary.

252 Taxation Review Authorities Act 1994, s 17(1).

253 Riley and others, above n 60, at 475.

254 Tax Administration Act 1994, s 136(16).

255 In Australia, the Federal Court has a fast-track system that aims to deliver judgments within six weeks of the trial. The fast-track system incorporates measures such as replacing full proceedings with a case summary, dealing with most interlocutory applications on the papers, holding scheduling conferences, reducing discovery, holding pre-trial conferences, and conducting "chess-clock" style trials: " Fast Track System" Federal Court of Australia <www.fedcourt.gov.au>. In Canada, taxpayers can opt to proceed with cases where the tax is less than $\$ 25,000$ via the informal process. The informal process encompasses more relaxed and flexible rules of evidence and representation, and it guarantees that the court fixes a hearing date within 180 days of the filing deadline for the reply and delivers judgments within 90 days of the hearing: MacGregor and others, above n 127, at 95-97.

256 Even supposing that tax judges need to adopt a different role to cater to unique procedural needs, there is little to suggest that those who are experts in taxation will be any more capable of performing this role. 
Judges with technical knowledge of an area are also better able to quickly identify the issues in a case, and have less need for expert witnesses. ${ }^{257}$ The expediency of case progression corresponds to the financial burden of running the courts, which is transferred to litigants paying hearing fees and to taxpayers funding the court system. Molloy argues that a further cost of an inefficient allocation of judicial time is that the system needs more judges, meaning additional judges must be appointed from a "lower strata" of candidates, in turn producing greater inefficiency and lower quality judgments. ${ }^{258}$

There are many stages to a tax dispute, and most of them are unduly time-consuming, whether specialists adjudicate them or not. Tax law does not involve a peculiar need for prompt resolution; usually the taxpayer has the ability to defer disputed payments, which alleviates the hardship of a long wait for a decision. ${ }^{259}$ However, the time per case of tax disputes is still unsatisfactory. Sir Ivor Richardson expressed an overall concern that "resolving tax disputes can take an unacceptably long time" and referred to the many years that pass before cases reached the Court of Appeal ${ }^{260}$ The disputes process has also been criticised for being time-consuming. ${ }^{261}$

Again, the best way to address these delays is by reforming the process' existing form rather than adding a specialist court or panel system to the High Court. The High Court will benefit from insights into the facts provided by the TRA and the disputes process will help to narrow the range of issues even coming before the court. A specialist court may replace the Authority but it would be unlikely to deal with cases more efficiently than the already specialised tribunal and neither option would address the wait before a case reaches court, which is a significant contributor to the delays in resolving tax cases.

\section{THE BENCHMARK FOR SPECIALISATION}

Tax law should not operate in isolation to the greater court system. Nor should any proposals for specialisation be considered without a view to the overall integrity of the court structure. The Law Commission's call for a "coherent and principled framework for the court system" identifies the need to consider specialisation holistically, with a view to creating a system that will be robust and

257 Katz observes that as well as the lesser need for expert witnesses to understand the complexities of the case, there is also likely to be less reliance on expert witness' conclusions, stating that "again it should not be overlooked that the skill of the specialist advocate can extend to the embellishment of a submission that might muster some credence before a generalist judge, but would readily be seen for what it is by a specialist judge: John Katz "Access to Justice from the Perspective of the Commercial Community: Judicial Specialisation" (2012) 18 AULR 37 at 39.

258 Molloy, above n 4, at 20-21.

259 Tax Administration Act 1994, s 128(2).

260 Richardson, above n 78.

261 Andrew Maples "Resolving Small Tax Disputes in New Zealand - Is There A Better Way?" (2011) 6 JATTA 96; James Peck and Andrew J Maples "The Tax Disputes Process in New Zealand: What about the Little Fellas?" (2010) 16 NZJTLP 348; Keating, above n 150; and Glazebrook, above n 86, at 15. 
responsive to a changing legal environment in the future. ${ }^{262}$ There is arguably a more principled basis for the specialisation of tax cases than there has been for many existing specialist courts. However, the benchmark for greater specialisation cannot be measured against current specialist courts, when many of these courts lack a firm and consistent rationale. There is a risk that accepting the existing specialist courts as a justification for further specialisation in the court system would open the floodgates to specialist courts or divisions fragmenting the High Court, as has occurred in the case of tribunals. This risk will become even more pressing should the Judicature Modernisation Bill be passed, empowering the Chief High Court judge to create new High Court panels.

Finding the appropriate benchmark for specialisation is not a matter of tallying Legomsky's criteria to establish whether there are more numeric benefits or disadvantages to specialisation. The criteria are not of equal weighting and some factors point more persuasively towards or away from greater specialisation. Finally, although it is helpful to consider the overseas experiences of specialisation, which can highlight certain frequent problems or benefits of specialisation, it is also inappropriate to rely heavily on the approaches taken in further jurisdictions as an indication of the correct level of specialisation. Specialisation is deeply contextual and the size and structure of New Zealand's court system does not provide a meaningful comparison on which to base the appropriate level of specialisation in New Zealand.

Instead, the conclusion must be based on a balancing of all of these factors, including the existing level and success of tax specialisation in New Zealand, the impact of specialisation on the court system as a whole, the successes and shortfalls of specialisation overseas, and nuanced evaluation of Legomsky's criteria.

\section{CONCLUSION}

On the surface, these factors may appear to point towards specialisation. The nature of tax law establishes it as an obviously complex and dynamic area of law that stands to benefit from specialisation. Many commentators have pointed to issues with the Taxation Review Authority and the general court system, questioning the institutional proficiency of these organisations in dealing with tax cases effectively and efficiently. The introduction of greater judicial specialisation seems an obvious answer to these problems, and it has been a broadly successful response in the United States, Canada and Australia. Judicial specialisation at the High Court level, through an independent court or internal panel, appears to hold plain and logical benefits; from greater judicial expertise flows higher quality decisions and increased efficiency. In light of this, it is tempting to suggest that a specialist tax court or panel is warranted in New Zealand.

However, a closer inspection reveals that greater specialisation is not without a price. Greater specialisation risks the development of idiosyncrasies in the development of the law, the 
fragmentation of the court system, and heightened controversy or perceptions of bias or appropriation by interest groups. This is not an abstract concern; criticisms of a lack of independence or appropriation are frequent across the overseas experience of specialisation and the history of judicial specialisation in New Zealand indicates a risk of specialist courts being used as a tool for policy intervention. Although the benefits of specialisation often vary in extent, the disadvantages associated with specialisation persist consistently across different applications of judicial specialisation and can be devastating to a court's perception.

Not only does specialisation come at a "price", but the supposed payoff of specialisation is unlikely to be realised in New Zealand. As well as heightening the problems of a clannish and insular grouping of professionals, the logistical realities of a small country like New Zealand prohibit the replication of successful specialist courts and panels of foreign jurisdictions, and outweigh any arguments for the greater efficiency of specialist courts. New Zealand lacks the critical tax case volume that would enable judges to develop a specialisation, and numerous procedural cases coming before the courts often do not benefit from the enhanced expertise, efficiency and internal consistency of specialisation. New Zealand simply does not have the size (both the size of the judiciary and the wider legal system) or resources to support tax judicial specialisation.

Additionally, New Zealand is further separated from other judiciaries with tax specialisation by the existence of effective extra-judicial means of tax specialisation, such as the comprehensive disputes process, which continues to evolve and develop to become more efficient and respected. The Taxation Review Authority continues to occupy an important position in New Zealand's court system, even though it has been affected by fluctuations in workload due to systemic and policy reforms of the tax system. Many of the issues faced by the tribunal and the disputes process revolve around how expensive and time-consuming these forums are. However, these issues are unlikely to be directly caused by problems associated with specialisation, but are more closely tied to the resourcing and management of these forums, which have been subject to a series of ongoing, promising reforms and enhancements since their fairly recent introduction. These reforms will also ensure that the critical perception of independence of the TRA is maintained.

Countless arguments can be made for the advantages and disadvantages of judicial specialisation. Yet overseas experience, an appreciation for the New Zealand context of specialisation and an evaluation of the normative debate, suggest that many of the theoretical benefits of specialisation would not translate to a small New Zealand context, while the inefficiencies, appropriation or bias risk, clannishness and isolated development of the law, would mean that the price that New Zealand would pay for a specialised judicial society in respect of tax law would far outweigh the benefits that specialisation purports to offer. 
VIII APPENDIX 1: NUMBER OF TAX REVIEW AUTHORITY CASES BY YEAR 263

\begin{tabular}{|c|c|c|c|}
\hline Year & \# of Cases & Year & \# of Cases \\
\hline 1974 & 30 & 1994 & 38 \\
\hline 1975 & 24 & 1995 & 45 \\
\hline 1976 & 22 & 1996 & 59 \\
\hline 1977 & 11 & 1997 & 41 \\
\hline 1978 & 25 & 1998 & 25 \\
\hline 1979 & 24 & 1999 & 28 \\
\hline 1980 & 33 & 2000 & 21 \\
\hline 1981 & 40 & 2001 & 9 \\
\hline 1982 & 62 & 2002 & 14 \\
\hline 1983 & 71 & 2003 & 29 \\
\hline 1984 & 89 & 2004 & 30 \\
\hline 1985 & 87 & 2005 & 16 \\
\hline 1986 & 110 & 2006 & 10 \\
\hline 1987 & 100 & 2007 & 13 \\
\hline 1988 & 82 & 2008 & 13 \\
\hline 1989 & 108 & 2009 & 19 \\
\hline 1990 & 132 & 2010 & 11 \\
\hline 1991 & 71 & 2011 & 12 \\
\hline 1992 & 86 & 2012 & 11 \\
\hline 1993 & 59 & 2013 & 11 \\
\hline
\end{tabular}

263 Courts of New Zealand does not publish statistics relating to the case volumes of specific tribunals, such as the Taxation Review Authority, but only publishes general workload statistics for a collection of 24 select tribunals, including the Taxation Review Authority. These statistics are instead compiled from the cases reported in the New Zealand Tax Cases journal. 


\section{APPENDIX 2: TAXATION REVIEW AUTHORITY} APPOINTMENTS 264

\begin{tabular}{|l|l|l|l|l|l|}
\hline Year & Name & Term & $\begin{array}{l}\text { Tenure } \\
\text { (Years) }\end{array}$ & $\begin{array}{l}\text { Appointment or } \\
\text { Re-Appointment }\end{array}$ & $\begin{array}{l}\text { Gazette Notice } \\
\text { (Gazette Year/ } \\
\text { Page Reference) }\end{array}$ \\
\hline 1981 & Paul Barber & $1981-1988$ & 7 & Appointment & $1981 / 2371$ \\
\hline 1982 & John Bathgate & $1982-1989$ & 7 & Appointment & $1982 / 1383$ \\
\hline 1984 & David Sheppard & $1984-1991$ & 7 & Appointment & $1985 / 129$ \\
\hline 1987 & Patrick Keane & $1987-1994$ & 7 & Appointment & $1987 / 1233$ \\
\hline 1988 & Paul Barber & $1988-1995$ & 7 & Re-Appointment & $1988 / 3646$ \\
\hline 1989 & John Bathgate & $1989-1996$ & 7 & Re-Appointment & $1989 / 865$ \\
\hline 1991 & Antony Willy & $1991-1998$ & 7 & Appointment & $1991 / 3223$ \\
\hline 1994 & Patrick Keane & $1994-2001$ & 7 & Re-Appointment & $1994 / 1400$ \\
\hline 2003 & Paul Barber & $2003-2006$ & 3 & Re-Appointment & $2003 / 843$ \\
\hline 2012 & Allison Sinclair & $2012-2017$ & 5 & Appointment & $2012 / 66$ \\
\hline
\end{tabular}

X APPENDIX 3: SITTING DAYS OF THE TAXATION REVIEW AUTHORITY 265

\begin{tabular}{|l|l|}
\hline Year & Sitting Days \\
\hline 1997 & 72 \\
\hline 1998 & 73 \\
\hline 1999 & 103 \\
\hline 2000 & 50 \\
\hline 2001 & 21 \\
\hline 2002 & 26 \\
\hline 2003 & 96 \\
\hline
\end{tabular}

264 Between 2006 and 2012, Paul Barber continued to act as an Authority, but there does not appear to be a record of this reappointment in the Gazette. Additionally, Board of Review Judge AJ Lloyd Martin continued to act as an Authority once the Board became the Taxation Review Authority.

265 These figures are taken from the Annual Reports of the Department of Courts in 2003 and 1999: Annual Report (Department for Courts, 1999) at 99; and Annual Report (Department for Courts, 2003) at 105. Following the merger of the Department of Courts and the Ministry of Justice in 2003, these statistics were no longer collected and published. The figures do not always accurately reflect the demand for the Authority because complex cases can skew the total sitting days. For instance, in 1995, a single case occupied an entire 43 sitting days: Case R 25 (1994) 16 NZTC 6,120 (TRA). 
APPENDIX 4: SPECIALISATION IN COUNTRIES OF SIMILAR SIZE

\begin{tabular}{|c|c|c|c|c|}
\hline Country & $\begin{array}{l}\text { Population } \\
\text { (million) }^{266}\end{array}$ & $\begin{array}{l}\text { Tax } \\
\text { Specialisation } \\
\text { (Court Level)? }\end{array}$ & $\begin{array}{l}\text { Tax } \\
\text { Specialisation } \\
\text { (Tribunal } \\
\text { Level)? }\end{array}$ & Other Notes \\
\hline $\begin{array}{l}\text { New } \\
\text { Zealand }\end{array}$ & 4.51 & No & Yes & $\begin{array}{l}\text { New Zealand's specialist } \\
\text { tribunal is the Taxation } \\
\text { Review Authority. }{ }^{267}\end{array}$ \\
\hline Ireland & 4.63 & No & Yes & $\begin{array}{l}\text { A specialist, independent } \\
\text { Appeal Commissioner } \\
\text { hears appeals by } \\
\text { taxpayers. }^{268}\end{array}$ \\
\hline Lebanon & 4.82 & Yes & Yes & $\begin{array}{l}\text { Although not solely a tax } \\
\text { specialisation, Lebanon has } \\
\text { administrative courts and } \\
\text { tribunals that hear tax } \\
\text { matters. }{ }^{269}\end{array}$ \\
\hline Norway & 5.04 & No & No & $\begin{array}{l}\text { There is no tax judicial } \\
\text { specialisation in Norway, } \\
\text { either curial or } \\
\text { adjudicative. }\end{array}$ \\
\hline Singapore & 5.41 & No & Yes & $\begin{array}{l}\text { Singapore has three Boards } \\
\text { of Review for tax matters; } \\
\text { the Goods \& Services Tax } \\
\text { Board of Review, the } \\
\text { Income Tax Board of } \\
\text { Review, and the Valuation } \\
\text { Review Board. } \\
\text { Ri1 }\end{array}$ \\
\hline
\end{tabular}

266 Population Statistics are taken from the projections for 2013 in: United Nations Department of Economic and Social Affairs/Population Division World Population Prospects: The 2012 Revision (New York, 2013) vol 1 at 57.

267 Taxation Review Authorities Act 1994.

268 Taxes Consolidation Act 1997 (Ireland), s 850; "Office of the Appeal Commissioners (for the purposes of the Income Tax Acts)" (1999) Office of the Appeal Commissioners <www.appealcommissioners.ie>.

269 OECD Global Forum on Transparency and Exchange of Information for Tax Purposes: Peer Review Report Phase 1: Legal and Regulatory Framework: Lebanon (OECD Publishing, 2012) at 11-12.

270 Bård Tønder "The Control of the Legislative and the Executive Power by Norwegian Courts" (24 June 2014) The Supreme Court of Norway <www.domstol.no>.

271 Singapore Income Tax Act (c 134) 2014, s 78; Income Tax (Board of Review) (Appeals Procedure) Regulations 1990; Goods and Services Tax Act (c 117a), s 50(10); Goods and Services Tax (Board of Review) Regulations 1993; Property Tax Act (c 254), s 68; and Valuation Review Board (Appeals Procedure) Regulations 1990. 


\begin{tabular}{|l|l|l|l|l|}
\hline Country & $\begin{array}{l}\text { Population } \\
\text { (million) }\end{array}$ & $\begin{array}{l}\text { Tax } \\
\text { Specialisation } \\
\text { (Court Level)? }\end{array}$ & $\begin{array}{l}\text { Tax } \\
\text { Specialisation } \\
\text { (Tribunal } \\
\text { Level)? }\end{array}$ & Other Notes \\
\hline Finland & 5.43 & Yes & Yes & $\begin{array}{l}\text { Finland has a Board of } \\
\text { Adjustment as the first } \\
\text { appeal authority and then } \\
\text { further appeals may go to } \\
\text { the Administrative } \\
\text { Court. }\end{array}$ \\
\hline Slovakia & 5.45 & Yes & $\begin{array}{l}\text { Slovakia has an } \\
\text { administrative law section } \\
\text { within its regional courts } \\
\text { that usually act as the court } \\
\text { of first instance in } \\
\text { administrative matters. }\end{array}$ \\
\hline Denmark & 5.62 & No & No & $\begin{array}{l}\text { The Danish National Tax } \\
\text { Tribunal hears tax matters. } \\
\text { The taxpayer may also } \\
\text { request an expert opinion at } \\
\text { several stages of the } \\
\text { dispute, including at the } \\
\text { City Court/High Court } \\
\text { stage. }\end{array}$ \\
\hline
\end{tabular}

272 "Tax Administration and Appeals" Vero: Finnish Tax Administration <www.vero.fi>.

273 OECD, above n 269, at 14.

274 OECD, above n 269, at 61 . 


\section{APPENDIX 5: CASES IN THE TAXATION REVIEW AUTHORITY, HIGH COURT, COURT OF APPEAL AND SUPREME COURT ${ }^{275}$}

\begin{tabular}{|l|l|l|l|l|}
\hline Year & TRA & High Court & Court of Appeal & Supreme Court \\
\hline 2008 & 13 & 64 & 9 & 4 \\
\hline 2009 & 19 & 60 & 17 & 5 \\
\hline 2010 & 11 & 65 & 11 & 6 \\
\hline 2011 & 12 & 57 & 12 & 5 \\
\hline 2012 & 11 & 56 & 8 & 7 \\
\hline 2013 & 11 & 63 & 15 & 2 \\
\hline
\end{tabular}

275 Courts of New Zealand, the Ministry of Justice and the IRD do not collect/publish statistics for the volume of tax cases before the courts or the Taxation Review Authority. Data relating to the Taxation Review Authority is compiled from the cases reported in the New Zealand Tax Cases journal. Data relating to the general courts is compiled from the Ministry of Justice's Judicial Decisions Online Database where cases have the Commissioner as a party. As a result, these statistics may also include cases that relate to ACC, liquidations or child support, for instance. 